\title{
Estudos Taxonômicos do gênero Bathysa C.Presl (Rubiaceae, Rondeletieae), no Brasil
}

\author{
Pedro Germano Filho ${ }^{1}$
}

\section{RESUMO}

O gênero Bathysa C.Presl, engloba cerca de 15 espécies, de árvores, arvoretas ou arbustos ocorrentes no Panamá, Guiana Francesa, Venezuela, Colômbia, Peru, Bolívia e Brasil. No Brasil ocorrem 7 espécies, todas exclusivas da mata atlântica das regiões sudeste e sul: B. mendonçaei, B. gymnocarpa, B. sylvestrae, B. australis, B. stipulata, B. nicholsonii e B. cuspidata.

São apresentados, para cada espécie, dados de fenologia, status de conservação e comentários. É proposto a sinonimização de B. meridionalis L.B.Sm. \& Downs, em B. australis (A.St.Hil.)Hook.f.

Palavras-chave: Rubiaceae, Bathysa, Taxonomia.

\begin{abstract}
The genus Bathysa C.Presl includes approximately 15 species of trees, small trees and scrubs, which are to be in Panama, French Guyana, Venezuela, Colombia, Peru, Bolivia and Brazil. In Brazil there are seven species, all of them in the south and Southeast region of the Atlantic Rain Forest: B. mendoncaei, B. sylvestrae, B. australis, B. stipulata, B. nicholsonii and B. cuspidata. Data of phenology, conservation categories, descriptions of each species are presented. A synonymy is proposed of B. meridionalis L.B.Sm. \& Downs to B. australis (A.St.-Hil.) Hook.f.
\end{abstract}

Kew words: Rubiaceae, Bathysa, Taxonony.

\section{INTRODUÇÃO}

A família Rubiaceae inclui aproximadamente 637 gêneros e cerca de 10.700 espécies (Robbrecht 1988), que ocorrem principalmente nas regiões tropicais e subtropicais, atingindo porém as regiões temperadas e frias da Europa e norte do Canadá (Barroso et al. 1986). As espécies desta família são facilmente reconhecidos pelas folhas simples, opostas e estípulas interpeciolares.
O estudo mais recente sobre a família, como um todo, no Brasil, foi elaborada por Schumann (1889), e embora constitua a base para qualquer estudo taxonômico do grupo, alguns trabalhos recentes com inúmeros dados novos, apontam para a necessidade de modificações tanto de interpretação morfológica de caracteres, como taxonômicas (Verdcourt 1958).

Os exemplares de Bathysa depositados nos herbários nacionais encontram-se em sua

\footnotetext{
* Dissertação de Mestrado apresentada à Coordenação do Curso de Pós-Graduação em Ciências Biológicas (Botânica) da Universidade Federal do Rio de Janeiro/Museu Nacional.

${ }^{1}$ Prof. Assistente, Universidade Federal Rural do Rio de Janeiro. Instituto de Biologia - Departamento de Botânica. Antiga Rodovia Rio-São Paulo, Km 47, 23851-970 - Seropédica-RJ-Brasil germano@rural.ufrrj.br
} 
maior parte indeterminados, com identificação duvidosa ou com atribuição errônea do autor da espécie, devido a escassez de bibliografia sobre o gênero e principalmente de um estudo abrangente sobre todos as espécies brasileiras. Além disso a distribuição das espécies de Bathysa, no Brasil, restringe-se quase apenas a mata atlântica, estando portanto, em sua maioria ameaçadas de extinção pelo impacto que esse ecossistema vem sofrendo pela ação antrópica. Assim o objetivo do presente trabalho é o estudo taxonômico de Bathysa no Brasil, acrescentando dados sobre distribuição geográfica, utilização das espécies, bem como o status de conservação das mesmas.

\section{MATERIAL E MÉTODOS}

Na elaboração do presente trabalho fezse o levantamento bibliográfico das publicações ligadas ao gênero e à família, obtendo-se cópias das descrições originais. Foram solicitadas exsicatas de herbários brasileiros e do exterior. Citados a seguir apenas aqueles dos quais se obteve coleções para análise, por ordem alfabética de suas siglas, de acordo com o Index Herbariorum (Holmgren et al., 1990),: CESJ, FCAB, GUA, HRCB, ICN, IPA, K, MBML, MO, PACA, R, RB, RBR, SP UB e UEC. Além do material herborizado, examinou-se tipos do Jardim Botânico do Rio de Janeiro, do Museu Nacional do Rio de Janeiro e fotografias de tipos provenientes do Royal Botanic Gardens de Kew e do Museu Nacional do Rio de Janeiro.

Nas descrições dos aspectos morfológicos gerais utilizou-se a terminologia empregada por Radford (1986) e Rizzini (1977), na descrição do padrão de nervação foi utilizada a nomenclatura proposta por Hickey (1973).

Para a ilustração do habitus foram utilizados material de herbário ou material fresco. Os detalhes morfológicos das flores e frutos foram feitos em câmara-clara acoplada a estereomicroscópio Wild M-5.
No material examinado os Estados estão citados de norte para o sul e os Municípios pela ordem alfabética, dentro de cada Estado. Coleções de mesma localidade, estão citadas em ordem cronológica crescente, as de mesma data em ordem crescente do número do coletor. Quando não constava na etiqueta o número de coleta, forneceu-se o número de registro de herbário. Utilizou-se as abreviaturas bt., fl., fr. e st. para indicar que o material está em botão, flor, fruto ou estéril respectivamente, bem como s.l., s.d., s.c. e s.n. indicando sem localidade, sem data, sem coletor e sem número de coleta.

Os dados de ocorrência, fenologia, nomes vulgares e usos foram obtidos das etiquetas das exsicatas, assim como da literatura e complementados com dados obtidos em observações de campo.

$\mathrm{Na}$ citação dos nomes vulgares, as referências sem indicação de autor, seguida de data dizem respeito a dados obtidos em etiquetas de herbário.

\section{RESULTADOS}

\section{HISTÓRICO}

O gênero Bathysa foi descrito por Karl (Carl, Carel, Carolus) Borivoj(Boriwog, Boriwag) Presl, no Botanische Bemerkungen em 1844, que o incluiu na tribo Rondeletieae. Segundo o autor, dentro dessa tribo, o gênero parecia mais próximo a Rondeletia, diferindo pelos lacínios do cálice truncados, filetes geralmente hirsutos na base, estilete espesso, obcônico e pela cápsula bipartida com os lacínios do cálice decíduos. Neste trabalho C.Presl redescreve $B$. stipulata, que havia sido descrita como Coffea stipulata por Velloso na Florae Fluminensis (1825).

Algumas espécies pertencentes ao gênero Bathysa já haviam sido descritas sob outros nomes. Saint-Hilaire (1824) em seus estudos sobre a flora brasileira, reconhece para o gênero Exostema duas espécies, E. cuspidata e E. australe. Naquele trabalho são fornecidas descrições, ilustrações, usos e 
nomes vulgares. Candolle (1828) no Prodromus redescreve sucintamente essas mesmas espécies também sob o gênero Exostema.

Klotzsch (1846) trata E. australe A.StHil. como Voigtia australe e E. cuspidatum como Schoenleinia cuspidata.

Hooker (1873) incluiu Exostema cuspidatum, E. australe e Coffea stipulata no gênero Bathysa.

Schumann (1889) em seu trabalho para a Flora Brasiliensis redescreve Bathysa, reconhecendo para o gênero 6 espécies: $B$. stipulata sinonimizada em Bathysa por Presl, $B$.australis e $B$. cuspidata sinonimizadas por Hooker (1876) e três novos taxons $B$. gymnocarpa, $B$. mendoncaei e $B$. nicholsonii. O autor apresenta ilustrações de B. cuspidata bem como uma chave para identificação das espécies, baseada na textura das folhas, número de peças florais, pilosidade da corola e dos filetes.

Glaziou (1905) em "Liste de Plantes du Brésil Central" cita o nome B. senaeii, baseado em espécime coletado por ele próprio em Sabará, Minas Gerais

Krause (1908), baseado em coleta de Ule, publica o nome B. peruviana, descrevendo posteriormente, nesse mesmo ano, a referida espécie.

Benoist (1920) descreve, baseado em espécime coletado por ele próprio, na Guiana Francesa, a espécie $B$. difformis. $\mathrm{O}$ autor afirma que a espécie difere das demais pelas inflorescências laterais e não terminais.

Standley (1931) publicou a espécie $B$. obovata que havia sido transferida por Schumann apenas em etiqueta de herbário da espécie Macrocnemum obovatum. Esta espécie havia sido nomeada também em etiqueta de herbário por Ruiz.

Smith \& Downs (1956) sinonimizam $B$. australis sob $B$. meridionalis alegando que a descrição e a figura originais de Exostema australe indicam flores 5-meras, não sendo portanto, possível usar esse nome como basiônimo de uma espécie que tem sempre flores 4-meras.
Williams (1965) descreve B. multiflora baseado em coleta feita por Bazán no Peru. $\mathrm{O}$ autor considera essa espécie bem distinta das duas que ocorrem no Peru, B. obovata (Ruíz) K. Schum. e B. peruviana Krause, posicionando-a mais próximo de $B$. australis do Brasil, havendo no entanto pequenas diferenças nas flores e folhas. Afirma ainda que a inflorescência dessa espécie não é a inflorescência típica do gênero.

Steyermarck (1966) faz uma nova combinação de Chimarrhis pittieri, descrita por Standley, para B. pittieri, sendo esse o primeiro registro do gênero para a Venezuela. Segundo o autor a espécie é melhor situada em Bathysa devido à combinação dos seguintes caracteres: estiletes parcialmente pilosos, estames exertos e a linha de pêlos na superfície externa da corola. O autor redescreve a espécie e apresenta ilustrações.

Dwyer (1968) descreve B. panamensis afirmando ser esta facilmente distinta pelas folhas truncadas ou brevemente auriculadas na base, sendo esse o primeiro registro do gênero fora da América do Sul.

Steyermark (1974) em seu trabalho para a flora da Venezuela afirma que existem 9 espécies de Bathysa na América do Sul, distribuídas no Peru, Brasil e Venezuela, ignorando as espécies já descritas para a Bolívia e Guiana Francesa.

Delprete (1996) fazendo um estudo comparativo entre três gêneros afins de Rubiaceae: Chimarrhis, Bathysa e Calycophyllum, transfere duas espécies de Chimarrhis para Bathysa fazendo $B$. bathysoides e $B$. perijaensis e torna $B$. difformis sinônimo de Chimarrhis turbinata. Esse mesmo autor em 1977 transfere Schizocalyx bracteosus para Bathysa, fazendo $B$. bracteosa.

Germano-Filho (1996) descreve $B$. sylvestrae baseado em coleta de Sylvestre na Reserva Ecológica Estadual do Paraíso, Cachoeira de Macacu, Rio de Janeiro. 


\section{MORFOLOGIA}

\section{Hábito}

São árvores, arvoretas ou arbustos que atingem até $12 \mathrm{~m}$. O caule é cilíndrico ou, às vezes, comprimido na base, ereto, com casca parda, castanho-acinzentada ou avermelhada, lisa ou com fina camada corticosa, longitudinalmente gretada, às vezes esfoliante em $B$. sylvestrae. Os ramos podem ser grossos ou delgados, cilíndricos ou tetrágonos às vezes comprimidos, castanhos ou castanhoacinzentados, glabros ou pilosos, com finas estrias longitudinais, lenticelas esparsas e longitudinalmente alongadas.

\section{Folhas e estípulas}

As estípulas são interpeciolares, imbricadas, caducas em B. cuspidata e $B$. gymnocarpa, persistentes nas demais espécies, lanceoladas ou truladas (em forma de colher de pedreiro, segundo Radford, 1986), com face ventral glabra, face dorsal com duas costas bem marcadas ou não, como em $B$. mendoncaei e B. gymnocarpa. Indumento tomentoso somente na região da nervura mediana ou até quase a margem. As estípulas de B. cuspidata permanecem unidas, caindo logo que as folhas primordiais se expandem (Fig. 9).

Em muitas plantas as estípulas de folhas em desenvolvimento possuem tricomas glandulares que secretam mucilagem, sendo tais estruturas chamadas coléteres (Fahn 1979). A mucilagem secretada pelos coléteres recobre e permeia os primórdios foliares e a gema, constituindo-se numa proteção. Em Rubiaceae os coléteres ocorrem exclusivamente na face ventral das estípulas (Lersten 1974). Quando as folhas jovens se expandem os coléteres secam e caem, sendo substituídos por tricomas multicelulares não secretores. Em espécimes de B. cuspidata observados no campo as estípulas das folhas jovens se apresentavam umedecidas por mucilagem na face interna e às vezes a mucilagem expandindo-se para a face externa.
Em algumas espécies de Psychotria ocorre uma interessante simbiose: a mucilagem secretada pelos coléteres abriga bactérias fixadoras de nitrogênio, que penetram através dos estômatos das folhas jovens desenvolvendo nódulos foliares (Esaú 1977). Robbrecht (1988) aceita o termo "galhas bacterianas" para a estrutura mencionada acima, afirma que a hipótese de fixação de nitrogênio é rejeitada e que em espécies africanas de Sericanthe, Paveta e Psychotria ocorrem as galhas.

As folhas são decussadas, 5,2-91,4x1,9$32,5 \mathrm{~cm}$; ovada estreito-ovada, obovada, estreito-elíptica ou oblanceolada; ápice acuminado ou obtuso; base cuneada, obtusa, arredondada ou truncada, simétrica, podendo ser assimétrica em $B$. sylvestrae. discolores em B. cuspidata e B. gymnocarpa, concolores nas demais espécies; tem textura cartácea ou membranácea; padrão de nervação broquidódromo, com nervura primária nítida em toda a sua extensão, não ramificada, proeminente na face dorsal; nervuras secundárias alternas ou subopostas, abruptamente curvadas.

\section{Inflorescência}

As inflorescências foram consideradas por vários autores como panículas, panículascimosas ou cimeiras terminais. No presente trabalho foram consideradas como tirsóides. São terminais, podendo ser axilares em $B$. gymnocarpa, com raque principal tetrágona, comprimida ou subcilíndrica, tomentosa ou velutina, curta ou bem desenvolvida atingindo até $24,5 \mathrm{~cm}$ em $B$. cuspidata e B. australis.

\section{Flores}

As flores são monoclinas, diclamídeas, actinomorfas, hermafroditas, são, via de regra, 4-meras; em B. australis e B. mendoncaei são 4-meras, às vezes 5-meras, sendo exclusivamente 5-meras em $B$. cuspidata; pediceladas, sésseis ou subssésseis.

O cálice possui lacínios triangulares, lanceolados, ou ovados, glabros internamente, pubescente externamente. Em B. sylvestrae 
os lacínios são hirtos internamente.

A corola é hipocrateriforme, com coloração amarelada amarelo-esverdeada ou cremes, sendo infundibuliforme e branca em B. cuspidata, internamente com linha de pêlos na região da inserção dos estames, externamente com linha vertical de pêlos abaixo da incisão dos lobos ou glabra; os lobos são imbricados na prefloração, cuculados ou planos, eretos ou reflexos como em $B$. cuspidata, largo-ovados, ovados ou oblongos.

Androceu isostêmone, estames alternipétalos, exsertos, introrsos, epipétalos; filetes glabros ou pilosos na base; anteras amareladas, basifixas em B. nicholsonii, dorsifixas nas demais espécies, rimosas, oblongas, elípticas, retas ou dispostas horizontalmente em B. gymnocarpa.

Gineceu com ovário ínfero, gamocarpelar, bicarpelar, bilocular, pluriovular, placentação axilar; disco nectarífero inteiro, anular, carnoso; estilete terminal, obcônico, grosso, com linhas verticais de pêlos na metade superior, bífido no ápice, com região estigmática papilosa na face ventral.

\section{Frutos e sementes}

Os frutos são cápsulas septicidas, elípticas, obcônicas ou ovadas, com valvas sublenhosas, amarelas, cobertas pelo hipanto castanho, persistente ou às vezes decíduo.

As sementes mostram-se muito semelhantes entre si. São aladas, com ala pouco desenvolvida, circundante ou se inserindo em somente uma das extremidades; são poligonais, podendo ser comprimidas, castanhas, testa escrobiculada; embrião com eixo hipocótilo-radícula, obovóide, bem desenvolvido, cotilédones largo-ovados.

\section{Distribuição Geográfica e Habitat}

As espécies são exclusivamente neotropicais, ocorrendo no Panamá, Venezuela, Guiana Francesa, Bolívia, Peru e Brasil, sempre em formações florestais de encosta em altitudes de 600-800(-1100) metros. No Brasil são encontradas no Distrito Federal e nos Estados do Espírito Santo, Bahia, Minas Gerais, Paraná, Rio de Janeiro, Santa Catarina, São Paulo e Rio Grande do Sul, quase que exclusivamente no domínio da Mata Atlântica, sendo que há um registro de $B$. cuspidata para a Serra de Caldas, em Caldas Novas, Goiás, podendo ser este um caso de encrave vegetacional. O Estado do Rio de Janeiro é o único onde ocorrem todas as espécies e o que possui o maior número de coletas. As espécies brasileiras são umbrófilas ou semiumbrófilas, crescendo à beira de caminhos ou riachos no interior das matas.

\section{Usos}

Algumas espécies de Bathysa são incluídas entre as falsas quinas que segundo Cunha (1937) englobam todas as plantas que contenham cascas de sabor amargo, de coloração avermelhada, amarelada ou acinzentada, capazes de fornecer uma alcoolatura ou decocto, usados como tônico ou febrífugo. As verdadeiras quinas diferem por possuir o quinino e ainda assim em percentagem mínima prevista pelo código farmacêutico.

Correa (1984) afirma que as cascas constituem tônicos que são freqüentemente empregados no tratamento de anemias, caquexias, febres palustres, ancilostomíase, convalescência, etc, além de fornecerem matéria corante.*

Segundo Hoehne (1939) tanto as falsas quanto as verdadeiras quinas são tóxicas para os herbívoros, já que esses nunca atacam as folhas de tais plantas.

O Instituto de Botânica de São Paulo (1990) relacionou B. stipulata dentre as espécies cujas sementes são passíveis de utilização na recuperação de áreas degradadas na Serra do Mar, em Cubatão.

Com o objetivo de conhecer as plantas usadas como medicinais pelos moradores da Parque Estadual da Serra do Brigadeiro-MG, Leoni (1995) constatou que a mucilagem de B. australis é empregada como cicatrizante.

Não se tem registro do aproveitamento 
econômico da madeira, sendo empregado somente como lenha ou em construções rústicas.

\section{Tratamento taxonômico}

\section{Descrição do gênero}

Bathysa C.Presl, Botanische Bemerkungen 84, 1844; Hook.f., in Benthan \& Hooker Genera Plantarum 2:49. 1876; K.Schum. in Martius, Fl. Bras. 6(6): 1-442. 1889; Steyemark, Bol. Soc. Ven. 26: 481. 1966.

Exostema A.St-Hil., Pl. Us. 14. 1824. Voigtia Klotzsch, Hayne Arzeigew. 14: 15. 1846.

Schoenleinia Klotzsch 1. c. Coffea Vell., Fl. Flum. 2: 63. 1825. Espécie Tipo: Bathysa stipulata (Vell.) C.Presl, l.c.

Árvores, arvoretas ou arbustos, ramos delgados ou grossos, cilíndricos ou tetrágonos, castanhos ou castanhoacinzentados, glabros ou pilosos. Folhas decussadas; estípulas persistentes ou caducas, lanceoladas ou truladas, membranáceas, face ventral glabra com coléteres na base, face dorsal tomentosa, com duas costas bem marcadas ou não; pecíolo, tomentoso ou velutino; lâmina ovada, obovada, obovado-lanceolada, elíptica, estreito-elíptica, elíptico-lanceolada, lanceolada ou oblanceolada, ápice acuminado ou obtuso, base cuneada, obtusa, arredondada ou truncada, simétrica ou assimétrica, face ventral glabra, pubescente. puberulenta ou tomentosa, face dorsal glabrescente, pubescente, pubérula, tomentosa ou velutina, cartácea ou membranácea, concolor ou discolor; padrão de nervação broquidódromo, nervura mediana saliente na face dorsal, nervuras secundárias alternas ou subopostas, com domáceas em tufos de pêlos nos encontros das nervuras. Inflorescências em tirsóides, terminais ou axilares, multifloros. Flores monoclinas, diclamídeas, 4-5-meras, actinomorfas, pediceladas ou sésseis. Cálice gamossépalo, lacínios triangulares ou lanceolados, glabros ou hirtos internamente, pubescente externamente. Corola gamopétala, hipocrateriforme ou infundibuliforme, amarelada, amareloesverdeada, creme ou branca, com linha de pêlos na altura da inserção dos estames internamente, com ou sem linha vertical de pêlos abaixo da incisão dos lobos externamente; lobos eretos ou reflexos, cuculados ou planos, largo-ovados, ovados ou oblongos. Androceu isostêmone; estames, exsertos; epipétalos; filetes levemente complanados ou subulados, glabros ou pilosos na base; anteras dorsifixas ou basifixas, introrsas, amareladas, bitecas, rimosas, oblongas, ou elípticas. Gineceu com ovário ínfero, gamocarpelar, bicarpelar, bilocular, pluriovulado, de placentação axilar; disco nectarífero inteiro, anular, carnoso; estilete com linhas verticais de pêlos na metade superior, ápice bífido, região estigmática papilosa na face ventral. Fruto cápsula septicida, elíptica, obcônica ou ovada, com hipanto persistente ou decíduo; valvas lenhosa amareladas. Sementes de tamanho reduzido, curtamente aladas, alas circundantes ou inseridas em somente uma extremidade, poligonais, comprimidas, pardas, testa escrobiculada; embrião com eixo hipocótilo-radícula obovóide, bem desenvolvido, cotilédones largo-ovados.

\section{Etimologia}

O gênero foi assim denominado devido a espessura do estilete, pois Bathysa deriva do grego bathys que significa espesso, sólido. 


\section{Chave para identificação das espécies}

1. Plantas férteis (com flores).

2. Flores 4-5-meras; corola hipocrateriforme, amarelada, verde-amarelada, ou branca, com até $6 \mathrm{~mm}$ de comp.

3. Ramos delgados, cilíndricos.

4. Folhas cartáceas, com face ventral glabra; filetes com tufos de pêlos na metade inferior 1. B. mendoncaei

4'. Folhas membranáceas, com face ventral pubérula ou pubescente; filetes glabros ou glabrescentes.

5. Folhas com base cuneada, simétrica; inflorescências terminais ou axilares; frutos com lacínios curtos

2. B. gymnocarpa

5'. Folhas com base truncada ou obtusa, assimétrica; inflorescências terminais; frutos com lacínios longos 3. B. sylvestrae

3'. Ramos crassos, tetrágonos.

6. Flores 4-meras ou 5-meras; filetes glabros

4. B. australis

6'. Flores sempre 4-meras; filetes pilosos.

7. Filetes pilosos apenas na base; anteras dorsifixas

5. B. stipulata

7'. Filetes pilosos na metade inferior; anteras basifixas

6. B nicholsonii

2'. Flores sempre 5-meras, corola infundibuliforme, branca, com mais de $9 \mathrm{~mm}$ de comp.

7. B. cuspidata

1'. Plantas sem flores (estéreis).

8. Estípulas caducas, unidas entre si, velutinas; folhas estreito-ovadas, verde-amareladas

7. B. cuspidata

8'. Estípulas persistentes ou caducas, livres entre si; folhas elípticas, oblanceoladas ou obovadas.

9. Ramos delgados, cilíndricos a subcilíndricos; folhas estreito elípticas.

10. Folhas glabras ou glabrescentes, de consistência cartácea

1. B. mendoncaei

10'. Folhas pubescentes ou hirsutas, de consistência membranácea.

11. Folhas com ápice agudo, base cuneada, simétrica

2. B. gymnocarpa

11 '. Folhas com ápice acuminado ou agudo, base obtusa, truncada ou cuneada, podendo ser assimétrica 3. B. sylvestrae

9. Ramos tetrágonos. Folhas obovadas a largo elípticas.

12. Estípulas com até $0,8 \mathrm{~cm}$ de largura. Folhas com ápice cuneado ou agudo.

5. B. stipulata

12'. Estípulas com mais de 1,2cm de largura; folhas com base obtusa ou arredondada. 13. Folhas cartáceas, elípticas ou obovadas, glabras ou pubérulas na face dorsal

6. B. nicholsonii

13'. Folhas membranáceas, largo-elípticas ou largo-obovadas, face puberulenta

4. B. australis 


\section{DESCRIÇÃO DAS ESPÉCIES}

1. Bathysa mendoncaei K. Schum., In Martius. Fl. Bras. 6(6): 239. 1889. Fig.: 3

Tipo: "Habitat in provincia Rio de Janeiro prope metropolin imperii: Regnel n. 95 ex p., Glaziou 7677 (R, P); Prope Petropolin: J. de Saldanha 5124; in Serra dos Orgaos: idem n. 6972; in provincia S. Paulo in silva primaeva prope Sorocaba: Mosén 3027 ex p". (síntipos).

Árvores com até 5m; ramos delgados, cilíndricos, castanhos, com estrias longitudinais. Estípulas persistentes, 1,4-2x0,5(-0,6)cm, lanceoladas ou truladas; lâmina com 13,7$18 \times 4,1-5,4 \mathrm{~cm}$, estreitamente elíptica a elíptica, ápice acuminado, base cuneada; face ventral glabra, face dorsal glabrescente; cartácea. Tirsóides terminais, 7-11,5cm de comp. Flores 4-meras ou 5-meras; cálice com lacínios de $1 \mathrm{~mm}$ de comp., triangulares; corola com 22,5mm de comp. hipocrateriforme, amareloesverdeada, glabra externamente; lobos eretos, largo-ovados; filetes levemente complanados, com tufo de pêlos na metade inferior, $2 \mathrm{~mm}$ de comp. anteras dorsifixas, oblongas, $1 \mathrm{~mm}$ de comp.; estilete piloso no ápice, com 5-6mm de comp. Cápsula elíptica ou obcônica, $5 \mathrm{~mm}$ de comp.

\section{ETIMOLOGIA}

O epíteto específico é uma homenagem ao Dr. Francisco Ribeiro de Mendonça, médico brasileiro, coletor da Flora Brasiliensis de Martius, e que, erroneamente, havia identificado material dessa espécie como $B$. gymnocarpa.

\section{DISTRIBUIÇÃO GEOGRÁFICA E ECOLOGIA}

B. mendoncaei ocorre nos Estados da Bahia, Rio de Janeiro e São Paulo.

\section{FENOLOGIA}

Floresce de novembro a dezembro, frutifica de novembro a junho.

\section{COMENTÁRIOS}

A espécie é próxima de $B$. stipulata diferindo pelos ramos cilíndricos, pelas flores que podem ser 4-5-meras e pela corola que é externamente glabra.

B. mendoncaei pode ser, segundo os critérios da UICN, considerada vulnerável (V). Tem distribuição geográfica restrita aos Estados da Bahia, Rio de Janeiro e São Paulo, ocorrendo em algumas áreas sob pressão de desmatamento ou em áreas protegidas.

\section{MATERIAL EXAMINADO}

Espírito Santo: Santa Teresa, 25.III.1988, Santos s.n.(MBML 5005). Bahia: Itacaré, s.d., s.c. (UB 68058); Rio de Janeiro: Nova Friburgo, 7.VI.1978 (fr), Araujo et al. 2080 (GUA); Petrópolis 14.XI.1874 (fl), Glaziou 7677 (R); Petrópolis, 1879 (fl), Saldanha s. n. (R 144653); Petrópolis, 1948 (fr), Goes \& Octavio 109 (RB); Petrópolis, XI.1944 (fl), Goes \& Dionisio 1166 (RB); Rio de Janeiro, s. d. (fl), Saldanha \& Glaziou 4963 (R); Rio de Janeiro, 14.XII.1944 (fl), Occhioni 311 (RB); Rio de Janeiro, 24.II.1959 (fr), Pereira 4523 \& Duarte (RB); Rio de Janeiro, 20.VI.1962 (fr), Lanna Sobr. 162 (GUA); Rio de Janeiro, 30.XII.1962 (fl), Lanna Sobr. 283 (GUA); Rio de Janeiro, 18.XII.1964 (fl), Emygdio 2054 et al. (GUA); Rio de Janeiro, 7.XI.1966 (bt), Guimarães 87 (IPA); Rio de Janeiro, 23.II.1972 (fr), Almeida 1253 (RB); Rio de Janeiro, 1.XII.1975 (fr), Vianna 622 (GUA); Rio de Janeiro, 2.II.1976 (fr), Araujo 977 (GUA); Rio de Janeiro, 27.XI.1981 (fl), Vianna 1563 (GUA); Teresópolis, 11.I.1883 (fl), Saldanha s.n. (R 144654); Teresópolis, 10.XII.1912 (fl), Vidal 5552 (R); Teresópolis, 28-VIII.1940 (fl), Brade 16641 (RB); Teresópolis, 16.V.1942 (fr), Dionisio \& Octavio 70 (RB); Teresópolis, 23.V.1942 (fr) Dionisio \& Octavio 91 (RB).

São Paulo: Cubatão, 10.XII.1994, Sugiyama 1277 (HRCB, SP, UEC). Ubatuba, s. d. (fl), Gentry \& Zardini 49347 (RBR, MO); Ubatuba, IV.1994, Furlan 1544 (SP). 
2. Bathysa gymnocarpa K.Schum. In Martius. Fl. Bras. 6(6): 238. 1889. Fig.: 4

Tipo: "Habitat in provincia prope metropolin imperii: Widgren, Burchell n. 1441, Regnell n. 95 ex p., Riedel n. 629; prope Botafogo: Martius; in Serra de Friburgo: J. de Saldanha n. 7089; in monte Corcovado: Warming, Burchell n. 1148, Schenck n. 2323, floret januario; in silvis umbrosis prope mandiocca: Riedel, floret martio; in silvis prope Castel Novo: Riedel n. 559; locis haud accuratius addictis probabiliter ejusdem. provinciae: Sello n. 228, Glaziou n. 707, 10914; in provincia S. Paulo prope Santos in silva primaeva ad Sorocaba: Mosen n. 3027 ex p., fl. Decembri." (Síntipos).

Árvores com até 7m; casca castanhoacinzentada, com placas longitudinais; ramos delgados, cilíndricos, com finas estrias longitudinais, tomentosos. Estípulas caducas, truladas, face dorsal velutina, 7,5-9 3 3,5-4,5mm; lâmina $\quad(5,2-) 6-15(-15,9) \times 1,9-5,4 \mathrm{~cm}$, oblanceolada a estreitamente elíptica, ápice acuminado, base cuneada, membranácea, face ventral pubérula, face dorsal pubescente. Tirsóides terminais ou laterais; raque principal velutina, atingindo $2,5-6 ., 5(-7,5) \mathrm{cm}$ de comp. Flores as terminais sésseis, as laterais pediceladas, 4-meras; cálice com lacínios triangulares, $0,5 \mathrm{~mm}$ de comp.; corola hipocrateriforme, amarelo-esverdeada, com linha vertical de pêlos abaixo da incisão dos lobos externamente; lobos eretos, cuculados, largo-ovados, 1,5-2,5mm de comp.; filetes glabrescentes na metade inferior, $4-5 \mathrm{~mm}$; anteras oblongas, geralmente dispostas horizontalmente, 0,8-1mm de comp.; estilete piloso no ápice, 5-6mm. Cápsula com 3-3,5mm comp.

\section{ETIMOLOGIA}

$\mathrm{O}$ autor não faz referência a etimologia na descrição original. Gymnocarpa deriva do grego e significa com os frutos nus, e provavelmente seja uma referência ao fato de, muitas vezes, o hipanto se destacar na maturação.

\section{DISTRIBUIÇÃO GEOGRÁFICA E ECOLOGIA}

A espécie ocorre em matas primárias ou secundárias nas regiões serranas dos Estados do Rio de Janeiro e São Paulo, na beira de picadas ou riachos dentro da mata.

\section{FENOLOGIA}

Floresce de setembro a abril, frutificando até julho.

\section{NOMES VULGARES}

"Guamirim" e "guapeba-branca" no Rio de Janeiro.

\section{COMENTÁRIOS}

B. gymnocarpa é facilmente diferenciada das demais pelos ramos muito delgados, pelas folhas membranáceas, discolores e pelas inflorescências pequenas, podendo ser terminais ou axilares. Destacase também pelo intenso perfume de suas flores.

Pode, segundo os critérios da UICN, ser considerada protegida. É muito freqüente nos Estados do Rio de Janeiro e São Paulo e mantém populações significativas em áreas de preservação tais como Parque Nacional da Tijuca, Reserva Biológica de Tinguá e Estação Ecológica do Paraíso, no Estado do Rio de Janeiro.

\section{MATERIAL EXAMINADO}

Rio de Janeiro: Angra dos Reis, Ilha Grande, 2.XII.1991 (fr), Samor 94 (RBR); Magé, 30.X.1984 (fr), Sonkin 347 (GUA); Nova Friburgo, 3.7.II-1883 (fl), Saldanha (R 144623); Nova Iguaçu, 14.XII.1991 (fl), SilvaNeto 05 (RBR); Nova Iguaçu, 19.XII.1991 (fl, fr), Germano-Filho 47 \& Silva-Neto (RBR); Nova Iguaçu, 19.XII.1991 (fr), GermanoFilho 50 \& Silva-Neto (RBR); Rio de Janeiro, 7.II.1944 (fl), Van 97 (R); Rio de Janeiro, 23.VII.1946 (fr), Duarte 163 (RB); Rio de Janeiro, XI.1948 (fl), Duarte 798 (RB); Rio 
de Janeiro, 15.II.1952 (fl), Brade \& Pereira 663 (RB); Rio de Janeiro, 10.XII.1864 (fl), Glaziou 705 (R); Rio de Janeiro, 15.XII.1965 (fl), Lanna Sobr. 1211 (GUA); Rio de Janeiro, 20.XI.1967 (fr), Carauta 496 (GUA); Rio de Janeiro, 17.XII.1967 (fl), Miirili 10 \& Carauta (GUA); Rio de Janeiro, 4.XII.1970 (fl), Lanna Sobr. 1838(GUA); Rio de Janeiro, 15.XII.1971 (fl), Rio de Janeiro, 21.II.1973 (fr), Carauta 2326 \& Oliveira (GUA); Lanna Sobr. 1211 (GUA); Rio de Janeiro, 12.XI.1975 (fr), Vianna 589 (GUA); Rio de Janeiro, 1.I.1976 (fl), Araujo 1196 (GUA); Rio de Janeiro, 22.IV.1980 (fl, fr), Rocha 39 (GUA); Rio de Janeiro, 22.IV.1980 (fr), Souza 36 (GUA); Rio de Janeiro, 10.III.1982 (fr), Ribeiro 1366 (GUA); Rio de Janeiro, 25.XI.1982 (fl), Vianna 1586 \& Leal (GUA); Rio de Janeiro, 2.XII.1982 (fl), Pedrosa 663 (GUA); Rio de Janeiro, 1983 (fl, fr), Martins 55 \& Leal (GUA); Rio de Janeiro, 16.XII.1983 (fl), Fernandes 619 (GUA); Rio de Janeiro, 1.X.1987 (st), Ribeiro 1129 (GUA); Rio de Janeiro, 9.XII.1987 (st), Ribeiro 1257(GUA); Rio de Janeiro, 1.II.1988 (fr), Ribeiro \& Zaú 1366 (GUA); Rio de Janeiro, 10.III.1988 (st), Ribeiro 1372 (GUA); Rio de Janeiro, 22.IV.1988 (fr), Zaú \& Flores s.n. (GUA 33978); Rio de Janeiro, 10.IX.1989 (fl), Ribeiro et al. 1111 (GUA); Rio de Janeiro, 4.I.1990 (fl), Pedrosa 1211 (GUA); Teresópolis, 4.IV.1917 (fr), Sampaio 2129 (R). São Paulo: Bertioga, 27.XI.1989 (fl., bt.), Silva et al. 22635 (UEC) Cubatão, 13.IX.1991 (fl.), Leitão-Filho \& Pagamo 25628 (UEC); Guarujá, 28.XI.1985 (fl., bt.), Silveira et al. 22866 (UEC); Guarujá, 29.XI.1985 (fl., bt.), Spironelo et al. (UEC 056243); Picinguaba, X.1992, Sanchez \& Pedroni 26 (HRCB), Ubatuba, 19.VI.1978 (fl), Silva 30 (UEC); Ubatuba 27-VII-1978 (fr), Silva 57 (UEC). Ubatuba, XI.1993, Toniato et al. 30155 (SP).

3. Bathysa sylvestrae Germano-Filho \& M. Gomes, Rev. Univ. Rural, Sér. Ciênc. da Vida 18(1). 1996

Fig.: 5
Tipo: Brasil, Rio de Janeiro, Cachoeira de Macacu, 28.IV.1992 (fr), Sylvestre et al. 787 (RB), (Holótipo RB !); Rio de Janeiro, Cachoeira de Macacu, 22.III.1992 (fr), Kurtz et al. s. n(RB); Rio de Janeiro, Cachoeira de Macacu, 28.IV.1992 (fr), Sylvestre 786 et al. (RB). (Parátipo RB !).

Árvores com até 9m; casca esfoliante; ramos delgados, cilíndricos, tomentosos nos dois últimos estrenós, depois hirsutos e glabros. Estípulas caducas, lanceoladas, face dorsal hirsuta na nervura central, 1-1,7mm de comp.; lâmina com 7-18x2-5,5cm, lanceolada, elípticolanceolada ou ligeiramente obovadolanceolado, ápice longamente agudo a caudado, base estreita obtusa, subaguda, truncada ou levemente cordada, podendo ser assimétrica, membranácea, discolor, face ventral pubescente, face dorsal hirsuta. Tirsóides terminais; raque principal tomentosa, de $4-6 \mathrm{~cm}$. Flores sésseis a curtamente pediceladas, aglomeradas no ápice dos ramos; c álice inconspícuo na flor e bem desenvolvido no fruto, lacínios lanceolados, $3 \mathrm{~mm}$ de comp, hirsutos na face externa, hirto na face interna; corola hipocrateriforme, com linha vertical de pêlos abaixo da incisão dos lobos externamente; lobos eretos, largo-ovados; filetes ligeiramente complanados, glabros; anteras dorsifixas, amareladas, elípticas. Cápsula com cálice marcescente, $4 \mathrm{~mm}$ de comp.

\section{ETIMOLOGIA}

O nome da espécie é uma homenagem a Lana da Silva Sylvestre, professora do Departamento de Botânica da Universidade Federal Rural do Rio de Janeiro, que foi um dos coletores do material que serviu de base para a descrição da espécie.

\section{DISTRIBUIÇÃO GEOGRÁFICA}

A espécie só ocorre no Estado do Rio de Janeiro estando restrita à Serra Queimada nos Municípios de Magé e Cachoeiras de Macacu na Reserva Ecológica Estadual do Paraíso, em altitude de cerca de $150 \mathrm{~m}$. 


\section{FENOLOGIA}

As únicas coletas até o presente, foram obtidas em abril, todas com frutos e somente foi encontrada uma flor, já murcha.

\section{COMENTÁRIOS}

A espécie é bem próxima de $B$. gymnocarpa diferindo pelo indumento menos intenso nas folhas, que têm a base obtusa ou truncada, que pode ser assimétrica, pelos lacínios do cálice mais longos principalmente no fruto, e pela presença de indumento na face interna do cálice.

B. sylvestrae segundo os critérios da UICN pode ser considerada rara $(\mathrm{R})$, porque estima-se que a sua população seja reduzida, pois só é representada em herbário pelas três coleções citadas como tipo.

\section{MATERIAL EXAMINADO}

O holótipo e os parátipos.

4. Bathysa australis (A. St.-Hil.) Hook. f. In Benth. et Hook. Gen. Pl. 2: 49. 1876; K.Schum., In Martius Fl. Bras. 6(6): 239. 1889. Fig.: 6

Tipo: Figura B em Plants Usuelles des Brasiliens 14, 1824 de A.St.-Hil.

Exostema australe A.St-Hil., Pl. Us. Bras. 14. 1824.

Voigtia australis Klotzsch, In Hayne Arzneigew 14: 16. 1846.

Bathysa meridionalis L.B.Sm. \& Downs, Sellowia 7: 88. 1956. nov. syn.

Arvoretas, às vezes árvores ou arbustos com até $8 \mathrm{~m}$, ramos crassos, tetrágonos, castanhos ou castanho-acinzentados, lenticelados; lenticelas esparsas, verticalmente alongadas. Estípulas com 3,0-3,7x1,2-2,1cm, persistentes, truladas; lâmina com 7,4-79,7x1,9$32,5 \mathrm{~cm}$, obovada, ápice acuminado ou obtuso, base cuneada, membranácea, face ventral glabra, face dorsal puberulenta. Tirsóides terminais, raque principal com $19,5-29 \mathrm{~cm}$.
Flores sésseis, 4-meras, algumas vezes 5meras; cálice com lacínios lanceolados ou ovados; corola hipocrateriforme, amarelada ou amarelo-esverdeada, externamente com linha vertical de pêlos abaixo da incisão dos lobos; lobos eretos, cuculados, largo-ovados, ovados ou oblongos; filetes levemente complanados, glabros, 2-3,5mm; anteras elípticas, com 0,8$1 \mathrm{~mm}$ de comp; estilete com 5-5,5mm. Cápsula 4-6mm de comp.

\section{ETIMOLOGIA}

O epíteto específico australis é uma referência à distribuição geográfica dessa espécie na região sul e sudeste do Brasil.

\section{DISTRIBUIÇÃO GEOGRÁFICA E ECOLOGIA}

A espécie ocorre no Distrito Federal e nos Estados do Espírito Santo, Minas Gerais, Rio de Janeiro, São Paulo, Paraná, Santa Catarina e Rio Grande do Sul, em matas de encosta ou de tabuleiro, sendo característica do estrato arbóreo inferior. É cultivada no Horto Florestal de São Paulo e no Jardim Botânico de Belo Horizonte. Rambo (1950) afirma ser a espécie muito rara na região da Porta de Torres, "tendo um único exemplar estéril na margem interna da Lagoa dos Quadros". Após a publicação desse trabalho de Rambo foram obtidas duas coletas naquela região (Batista s. n., Waechter 1035).

\section{FENOLOGIA}

Floresce de setembro a março, frutificando de setembro a agosto.

\section{NOMES VULGARES E USOS}

Minas Gerais: "pau-de-colher" (Leoni, 1995); Rio de Janeiro: "quina-do-mato"; São Paulo: "fumão", "araribão"; Santa Catarina: "cauassú”, "quina-do-Paraná" (Correa, 1931), "macuqueiro". Segundo Correa (1931) os indivíduos dessa espécie têm cascas amargas, tônicas e febrífugas, pelo que fazem parte das chamadas "falsas quinas". 


\section{COMENTÁRIOS}

B. australis possui folhas que lembram as folhas do fumo na textura e na cor, tendo por esse motivo recebido a denominação popular de "fumão". A espécie, no aspecto vegetativo, assemelha-se a duas outras espécies de Rubiaceae Rustia formosa e Simira viridifolia. Da primeira difere-se por possuir coloração mais clara e fosca nas folhas que são mais largas e membranáceas, da segunda pelos ramos tetrágonos enquanto os de Simira são cilíndricos e sua casca interna se torna avermelhada quando exposta ao ar. A espécie, segundo os critérios da UICN, pode ser considerada protegida, pois tem ampla distribuição e ocorre em áreas de preservação tais como floresta protetora da Represa de Ribeirão das Lajes, Reserva Biológica do Tinguá, Parque Nacional da Tijuca e Jardim Botânico de Belo Horizonte.

\section{MATERIAL EXAMINADO}

Distrito Federal: Brasilia, 08.X.1968, Gomes s.n. (UB 48247); Minas Gerais: Belo Horizonte, 17.I.1933 (fr.), Barreto 3641 (RB); Juiz de Fora, 21.I.1988, Garcia 06 (CESJ)Juiz de Fora, 22.IX.1988 (fl.), Krieger s.n. (CESJ 22730); Viçosa, 24.II.1934 (fl.), Kuhlmann s. n. (RB 2278); Viçosa, Kuhlmann s. $n$. 4.XII.1934 (fl.). Rio de Janeiro: Itatiaia, I.1939 (fl.), Langstyak 250 (R, RB); Itatiaia, $3 . X .1990$ (fr.), Germano-Filho 29 (RBR); Nova Iguaçu, 19.XII.1991 (fl., fr.), GermanoFilho 49 (RBR); Petrópolis, 1879 (fl.), Saldanha s. n. (R 144652); Petrópolis, 23.XII.1882 (fl.), Glaziou 13950 (R); Petrópolis, XII.1943 (fl.), Góes \& Constantino 1097 (RB); VII.1971 (fl.), Krieger \& Urbano 9622 (RB); Petrópolis, XI.1944, Góes \& Constantino 1185 (RB); Piraí, 21.II.1984 (fl., fr.), Machline et al. 196 (RBR); Piraí, 3.III.1988 (fr.), Barbosa et al. 1000 (RBR); Piraí, 10.V.1988 (fr.), Barbosa et al. 1030 (RBR); Piraí, 24.IV.1989 (fr.), Pantoja 60 \& Germano-Filho (RBR); Piraí, 24.IV.1989 (fr.), Pantoja 62 \& Germano-Filho (RBR); Piraí, 1.X.1990 (fr.), Conde 375 (RBR);
Rezende, 19.II.1966 (fr.), Lanna Sobr. 1232 (GUA); Teresópolis, 16.XII.1942, Barros 1187 (RB); Teresópolis, 14.VI.1948, Rizzini 49 (RB); Teresópolis, s. d. (fr.), Sucre 10762 (RB).São Paulo: Atibaia, 04.V.1990, Bernacci et al 21055 (UEC); Cananéia, 11.I.1995 (fl.), Bernacci et al. 1124 (SP, UEC); Caraguatatuba, 22.III.1976 (fl.), Davis et al. 59944 (UEC); Cunha, II.1994, Baitello 480 (SP); Cunha, 21.II.1996, Costa 184 et al. (SP, UEC); Eldorado, 09.II.1995, Árbocz et al. s.n. (UEC 073266); Eldorado, IX.1995, V.C. Souza et al. 9005 (SP); Ferraz de Vasconcelos, IV.1996, Garcia et al. 823 (SP); Horto da Cantareira, XI.1933, Hoehne s.n. (SP); Iporanga, 23.IV.1994 (fr.),.Souza et al. 5942 (HRCB, SP, UEC); Jundiaí, s. d. (fr), LeitãoFilho et al. 1595 (UEC); São Paulo, 5.I.1985 (fr), Gentry 49208 \& Zardini (RBR, MO); São Paulo, s. d. (fl), s. c. (R 144659); Parelheiros, II.1995, Godoy et al. 399 (SP); São José do Barreiro, VII.1994, Rossi \& Catharino 1571 (SP); São Paulo, X.1901, Puiggari s.n. (SP 11392); São Paulo, I.1918, Hoehne 1236(SP); São Paulo, VIII.1939, Koscinski s.n. (SP 41429); São Paulo, V.1994, Garcia et al. 477 (SP); São Paulo, V.1995, Aguiar et al. 564 (SP); São Paulo, V.1996, Souza et al. 06 (SP); São Roque, 02.XII.1993, Cardoso-Leite \& Oliveira 299 (UEC); Sete Barras, 19.IV.1967 (fr.), Hoehne 6186 (SP); Ubatuba, VI.1970, Silva s.n. (UEC 1307); Ubatuba, XII.1978, Silva 75 (UEC); Ubatuba, 19.VI.1990, Silva 30 (UEC); Ubatuba, III.1991, Rodrigues et al. s.n. (UEC 25086); Ubatuba, IV.1991 (fr.), Kirizawa 2481 \& Lopes (SP); Ubatuba, 24.IV.1993, Martini et al. 30125 (SP, UEC); Ubatuba, IV.1994, Furlan et al. 1509 (HRCB, SP); Ubatuba, 3.II.1996 (fl.), Leitão-Filho et al.34791 (SP); Vinhedo, 27.IX.1977 (fr.), Ramos et al. s. n., (UEC 13410). Paraná: Campina Grande Sul, 12.II.1968 (fl.), Hatschbach 20277 (RB); Jaguariaiva, 23.III.1968 (fr.), Hatschbach 18935 (RB); Morretes, 16.XI.1978 (fl.), Hatschbach 41726 (UEC); Ponta Grossa, 19.XII.1943 (fl.), Krieger s. n. (SP 51461). 
Santa Catarina: Brusque, 7.IX.1948 (fl.), Reitz 5212 (PACA); Brusque, 3.II.1950 (fr.), s. c. (PACA 58276); Brusque, 18 e 19.II.1952 (fr.), Smith \& Veloso 5665 (RB); Brusque, 3.I.1949 (fl.), Reitz 4802 (PACA); Luiz Alves, 22.I.1948 (fr.), Reitz 2897 (PACA); Nova Trento, VI.1938 (st.), Rambo s. n. (PACA 3336); Tijuca,, VI.1938 (st.), Rambo s. $n$. (PACA 3336); Florianópolis, 13.I.1948 (fl.), Sehnen 3062 (PACA); Vidal Ramos-Sabiá, 26.VI.1952 (bt.), Klein 2225 (PACA). Rio Grande do Sul: Torres, X.1964, Baptista s. n. (ICN); Torres, 18.XI.1978 (fl.), Waecther 1035 .

5. Bathysa stipulata (Vell.) C.Presl, Botanishe Bemerkungem 84. 1844. Fig.:7

Coffea stipulata Vell., Fl. Flum. 2: 63. 1825. t. 17

Shoenleinia barbinervis Klotzsch. In Hayne Arzneigew. 14. 1846.

Tipo: "Habitat in Brasilia ad Rio de Janeiro, ubi legit Lhotsky s. n.” (Holótipo).

Árvores, arvoretas, arbustos com até $12 \mathrm{~m}$; ramos delgados, tetrágonos, os mais novos comprimidos, finamente gretados, castanhos, lenticelados; lenticelas esparsas, verticalmente alongadas. Estípulas com 1,31,8(-2,3)x0,4(-0,8)cm; lanceoladas; Lâmina com 10-24,7x2,8-11,6cm estreito-elíptica, ápice obtuso a acuminado, base cuneada, cartácea, glabra, glabrescente nas nervuras. Tirsóides terminais, com 5,5-10,5cm de comp. Flores sésseis, 4-meras; cálice com lacínios triangulares, $1 \mathrm{~mm}$ de comp.; corola hipocrateriforme, amarelo-esverdeada, com linha vertical de pêlos abaixo da incisão dos lobos externamente; lobos eretos, largamente ovados, $2 \mathrm{~mm}$; filetes com tufo de pêlos na base , 1-2,5mm; anteras com ca. $1 \mathrm{~mm}$. Estilete com 5-5,5mm. Cápsula com 3-4mm de comp.

\section{ETIMOLOGIA}

A espécie recebeu o nome de $B$. stipulata provavelmente devido às estípulas conspícuas em relação às das outras espécies do gênero Coffea, onde essa espécie foi primeiramente incluída.

\section{DISTRIBUIÇÃO GEOGRÁFICA}

B. stipulata ocorre na Serra do Mar, em vegetação primária ou secundária nos Estados do Rio de Janeiro e São Paulo. É cultivada na Estação Experimental de Café em Coronel Pacheco, Minas Gerais.

\section{FENOLOGIA}

Floresce de agosto a dezembro frutificando de setembro a junho.

\section{NOMES VULGARES E USOS}

Minas Gerais: "autuparana" (Correa, 1984), "folha-larga"; São Paulo: "antuparana" (Secretaria de Meio Ambiente de São Paulo, 1990); Rio de Janeiro: "quina-da-serra", "quina-do-mato" e "pau-de-colher" (Cunha, 1937).

Correa (1984) afirma que a casca de $B$. stipulata contêm um princípio gomo-resinoso amargo, matéria extrativa e matéria corante.

B. stipulata foi relacionada entre as espécies arbustivo-arbóreas cujas sementes são passíveis de utilização na recuperação da vegetação na Serra do Mar da região de Cubatão no Estado de São Paulo.

\section{COMENTÁRIOS}

B. stipulata é distinta das demais espécies pelos ramos tetrágonos, folhas cartáceas, estreito-elípticas, com base cuneada e filetes pilosos na base.

A espécie pode ser considerada, segundo os critérios da UICN, como vulnerável (V), porque poderá tornar-se em perigo se não forem tomadas medidas conservacionistas.

\section{MATERIAL EXAMINADO}

Minas Gerais: Coronel Pacheco, 15.XII.1941 (fl), Heringer 863 (SP). Santa Rita de Jacutinga, 13.II.1972 (fr.), Krieger 11530 (CESJ). Rio de Janeiro: Angra dos Reis, 14.II.1984 (fr), Araujo 6074 (GUA); 
Nova Iguaçu, 5.XII.1987 (fl), Gomes 278 (RB); Petrópolis, XI.1944 (fl), Goes \& Dionisio 1186 (RB); Piraí, 21.XI.1984 (fl, fr), Machline et al. 196 (RBR); Piraí, 8.IV.1991 (fr), Peixoto et al. 6242 (RBR); Piraí, 8.IV.1991 (st), Peixoto et al. 6244 (RBR); s.l., s.d. (fr), Duarte \& Pereira s.n. (RB 104139). Rio de Janeiro, 25.VII.1940 (fr), Pereira s. n. (R 144636); Rio de Janeiro, 19.XII.1868 (fl), Glaziou 3031 (R); Rio de Janeiro, 1883 (fl), Saldanha s. n. (R 150177); Rio de Janeiro, 16.VI.1932 (fr), Brade 11933 (R); Rio de Janeiro, 24.II.1959 (fl), Pereira 4523 (RB); Rio de Janeiro, 22.II.1965 (fr), Lanna Sobr. 785 (GUA); Rio de Janeiro, 25.II.1972 (fr), Almeida 1291 (RB); Rio de Janeiro, 13.IX.1984 (fl), Cominote 92 (GUA); Rio de Janeiro, 11.X.1990 (fl), Germano-Filho et al. 26 (RBR); Rio de Janeiro, 26.XI.1990 (fl), Marquete et al. 310 (RB); Rio de Janeiro, 24.V.1975 (fr), Sucre 9983 (RB); Rio de Janeiro, 16.XII.1931 (fl, fr), Vitorio s. n. (RB 111093). São Paulo: Bertioga Mirim, 26.X.1993 (fl.), Custódio-Filho 1747 (SP); Cunha, 29.III.1994 (fr.), Baitello 480 (HRCB); Paraibuna, 25.II.1984 (fl), Sheperd \& Tamashiro s. n. (UEC 35831); Salesópolis, 03.IX.1994 (fl., fr.); Kiyama 30 et al. (HRCB), Salesópolis, 27.XI.1948 (fl.); Kuhlmann 1707 (USP); Salesópolis, 03.IX.1994 (fl., fr.); Kiyama 30 et al. (HRCB).

6. Bathysa nicholsonii K.Schum. In Martius, Fl. Bras. 6(6): 236. 1889.

Fig.: 8

Tipo: "Habitat in Brasilia australi: Glaziou 10902 (Parátipo K, fotografia do parátipo RBR ); 13949” (Lectótipo R, aqui designado, fotografia do lectótipo RBR !).

Árvores com até $7 \mathrm{~m}$, casca castanha, com placas longitudinais; ramos crassos, tetrágonos, castanho-acinzentados, lenticelados; lenticelas esparsas verticalmente alongadas. Estípulas persistentes, lanceoladas ou truladas, face dorsal conspicuamente costada, tomentosa na região intercostal, 2,12.7(-3,6)x(0,8-)1,6-1.9cm.; lâmina com (10,3)17,4-25(-29,7)x5,3-16cm, elíptico-obovada, ápice acuminado, base aguda, arredondada ou truncada, cartácea, subconcolor, face ventral glabra, geralmente brilhante, face dorsal pubérula. Tirsóides terminais; raque principal tomentosa, 7,2-12,1 cm. Flores sésseis, 4meras; cálice com lacínios, largo-ovados, 0,71,0mm de comp.; corola hipocrateriforme, amarelo-esverdeada, externamente com linha vertical de pêlos abaixo da incisão dos lobos, 2-2,5mm se comp.; lobos eretos, planos, largoovados, (2-)2,5mm de comp.; filetes com tufo de pêlos na metade inferior, com $2 \mathrm{~mm}$; anteras elípticas, 0,8-1mm de comp., estilete com 5$6 \mathrm{~mm}$. Cápsula com $5 \mathrm{~mm}$ de comp.

\section{ETIMOLOGIA}

O epíteto específico é uma homenagem a George Nicholson, curador do herbário do Jardim Botânico de Kew, e que segundo o autor foi quem primeiro observou os caracteres diagnósticos importantes, para a distinção da espécie tais como as inflorescências aglomeradas e as folhas crassas, coriáceas.

\section{DISTRIBUIÇÃO GEOGRÁFICA}

Ocorre no Estado do Rio de Janeiro no Parque Nacional da Tijuca e na Reserva Biológica de Tinguá onde é encontrada na orla da mata associada com indivíduos de $B$. cuspidata e no Estado de Minas Gerais.

\section{FENOLOGIA}

Floresce de outubro a março, frutificando até julho.

\section{NOMES VULGARES} mato".

Rio de Janeiro: "bapebucu" e "quina-do-

\section{COMENTÁRIOS}

A análise da fotografia de um dos síntipos indicou que o número do coletor é 10902 e não 10912, como consta na descrição original. A análise do material tipo depositado no herbário 
do Museu Nacional do Rio de Janeiro (R), perfeitamente coadunante com a descrição da espécie e em perfeito estado de conservação possibilitou a eleição de um lectótipo para esta espécie. O material examinado, tanto fresco quanto seco, indica que os caracteres usados pelo autor da espécie, em sua chave, como folhas coriáceas e flores aglomeradas nas inflorescências, não são comuns a todos os espécimes analisados e não foram, por isso utilizados na chave analítica apresentada no presente trabalho, sendo substituídos por caracteres como pilosidade na corola e nos filetes, espessura dos ramos e formato e da base das folhas.

B. nicholsonii é encontrada na Reserva Biológica do Tinguá associada à populações de B. cuspidata.

Segundo os critérios da UICN a espécie pode ser considerada rara (R). A análise de material de herbário e as expedições de campo levam a crer que $B$. nicholsonii tenha populações de tamanho reduzido, nos Estados do Rio de Janeiro e Minas Gerais.

\section{MATERIAL EXAMINADO}

Minas Gerais: Belo Horizonte, 10.II.1968 (fr.), Irwin et al s.n. (UB);. Cataguazes, 26.VI.1935 (fr.), Barreto 4051 \& Moreira (RB); Juiz de Fora, 26.I.1988, Garcia 12 (CESJ); Juiz de Fora, III.1994, Silveira \& Lisboa s.n.(CESJ 27918); Manhuaçú, s.d.; Heringer s.n. (UB); Santana do Riacho, s.d., Pirani \& Cordeiro s.n. (UB 687554); Rio de Janeiro: Nova Friburgo, (st.), 22.XI.1988, Nadruz 424 et al. (RB); Nova Friburgo, 15.IX.1987, Sobral et Siqueira s.n. (FCAB); Nova Iguaçu, 14.XII.1991 (fl.), Silva-Neto 06 (RBR); Nova Iguaçu, 19.XII.1991 (fl), Germano-Filho 46 \& SilvaNeto (RBR); Nova Iguaçu, 19.XII.1991 (fl.), 48 (RBR); Nova Iguaçu, 28.XII.1962 (fl.), Fromm 1279 (R); Petrópolis, 12.XI.1882 (fl.), Glaziou 13949(R); Petrópolis, s. d. (fr.), Goes \& Octavio s. n. (RB 61888). Petrópolis, 02.XI.1970(fl.), Krieger 9612 (CESJ).
7. Bathysa cuspidata (A.St.-Hil.) Hook.f.. In Benth. et Hook. Gen. Pl. 2: 49. 1876; K.Schum., In Martius, Fl. Bras. 6(6): 237. 1889.

Fig.: 9

Exostema cuspidatum A.St.-Hil., Pl. Us. 14. 1824.

Schoenleinia cuspidata Klotzsch. In Hayne Arzneigew. 14. 1846.

Tipo: Figura A em Plants Usuelles des Brasiliens 14. 1824 de Saint-Hilaire.

Arbustos ou arvoretas com até $6 \mathrm{~m}$, casca castanha; ramos delgados, cilíndricos, os mais novos comprimidos, castanhos, lenticelados; lenticelas alongadas, verticais, esparsas. Estípulas caducas, unidas entre si, tomentosas, com 2,1-9x1-3cm.; lâmina, com 12,8-91,4x6,5$31 \mathrm{~cm}$, obovada a obovado-lanceolada, ápice acuminado, base cuneada, membranácea, face ventral velutina, face dorsal velutina com coloração verde-amarelada. Tirsóides terminais; raque principal comprimida, com 16,7-24,5cm. Flores sésseis ou subssésseis, 5meras; cálice com lacínios largo-triangulares, $0,5 \mathrm{~mm}$ de comp.; corola infundibuliforme, branca, 10-11 mm de comp; lobos reflexos, planos, obovado-lanceolados a obovados, 6$9 \mathrm{~mm}$ de comp.; filetes com tufo de pêlos na base, 6-7mm; anteras dorsifixas, oblongas, ápice acuminado, base sagitada, $4 \mathrm{~mm}$ de comp.; estilete piloso no ápice, com $10 \mathrm{~mm}$. Cápsula com 3-5mm de comp.

\section{ETIMOLOGIA}

O epíteto específico origina-se do latim cuspidatus, que significa dotado de cúspide ou ponta, referindo-se ao ápice das folhas.

\section{DISTRIBUIÇÃO GEOGRÁFICA}

A espécie ocorre na Serra do Mar nos Estados do Rio de Janeiro e São Paulo, região serrana de Minas Gerais e Espírito Santo e existe uma coleta, em mata de galeria, na Serra de Caldas, em Goiás. 


\section{FENOLOGIA}

Floresce de abril a julho, frutificando de julho a maio.

\section{NOMES VULGARES E USOS}

Rio de Janeiro: "quina-do-mato" (Correa, 1984), "quina-cinzenta”.(Cunha, 1937).

Segundo Correa (1984) as cascas de $B$. cuspidata, espessas e vermelhas, constituem tônicos amargos empregados em anemias, caquexias, febres palustres, ancilostomíases, convalescências, etc.

\section{COMENTÁRIOS}

A espécie é bem distinta das demais pelas folhas muito grandes, membranáceas, verdeamareladas. Possui estípulas, grandes, caducas, que se abrem por somente uma das margens. Suas flores são sempre pentâmeras, brancas, com corola infundibuliforme. Pode ser segundo os critérios da UICN considerada protegida, porque tem ampla distribuição, ocorre em áreas de preservação sendo bem representada nos herbários.

\section{MATERIAL EXAMINADO}

Espírito Santo: Ibatiba, 04.VIII.1983, Hatschbach 46687 (UB); Itaguassú, 15.V.1946 (fl.), Brade 18211 et al. (RB); Serra para Vargem Alta, 4.V.1966 (fr.), Duarte 9730 (RB). Goiás: Caldas Novas, 10.VII.1976 (fl.), Hatschbach 38793 (UEC). Minas Gerais: Coronel Pacheco, 5.VII.1944 (fl., fr.), Hering s. n. (SP 51957); Juiz de Fora, 26.IV.1985 (fl.), F. R. S. P. et al. 20576 (UEC); Juiz de Fora, 13.III.1993, Gomes-Filho s.n. (CESJ 26594). Juiz de Fora, IV.1994, Silveira \& Lisboa s.n. (CESJ 27923). Reserva Florestal do Rio Doce, 30.VIII.1973 (fr.), Sucre 10151 et al. (RB); Serra da Cayana, 3.VII.1888 (fr.), Schwacke 6171 (RB); Viçosa, 7.III.19731 (fr.), Kuhlmann s. n. (RB 14097). Rio de Janeiro: Nova Friburgo, 5.II.1883 (fr.), Bacelli s. n. (R 144638); Nova Iguaçu, 4.V.1992 (fl.), Germano-Filho 53 (RBR); Nova Iguaçu, 5.V.1992 (fl.), Silva-
Neto 22 (RBR); Itatiaia, 24.V.1955 (fl.), Brade s. n. (RB 26175); Paracambi, 8.IV.1986 (fr.), Carauta et al. 5299 (GUA, RBR); Petrópolis, 21.II.1873 (fl.), Glaziou 6565 (R); Petrópolis, Quitandinha, 1948 (fl.), Goes \& Octavio 17 (RB); Teresópolis, 1879 (fr.), Saldanha s. n. (R 144640); Teresópolis, V.1883 (fr.), s.c. (R); São Paulo: Queluz, 23.V.1996 (fl.); Macias 96.18 et al. (SP); Serra da Mantiqueira, I.1885 (fr.), Saldanha s. n. (R 150184).

\section{CONCLUSÕES}

O estudo taxonômico das espécies de Bathysa, que abrange um total de 15 espécies, levou ao reconhecimento de 7 espécies para Brasil,.

Foram aceitas todas as espécies propostas por Schumann (1889) em seu trabalho para a Flora Brasiliensis, acrescentando ao seu estudo uma nova espécie B. sylvestrae.

O binômio B. senaeii citado por Glaziou (1905) não foi considerado no presente trabalho. $\mathrm{O}$ espécime que originou o nome, coleta do próprio autor efetuada em Sabará, Minas Gerais, não foi localizado, bem como não se obteve, até o presente, exemplares no campo nessa, pelo que se considera um nome nudun.

As espécies desse gênero ocupam sempre ecossistemas florestais. No Brasil estão praticamente restritas à Mata Atlântica do sul e sudeste do país, ocorrendo predominantemente em mata de encosta, mais raramente em mata de altitude.

Das espécies estudadas somente uma é exclusiva do Estado do Rio de Janeiro ( $B$. sylvestrae). B. cuspidata, que apresenta ampla distribuição, foi documentada em área de floresta úmida no Estado de Goiás.

B. sylvestrae e B. nicholsonii são consideradas raras, segundo os critérios da IUCN. Suas populações parecem hoje restritas e fragmentárias. $B$. mendoncaei e $B$. stipulata foram consideradas vulneráveis, pois embora representadas em áreas de proteção 
ambiental, não são espécies muito freqüentes nessas localidades, ocorrendo também em áreas não protegidas, sujeitas a impactos ambientais. B. australis, B. gymnocarpa e $B$. cuspidata são consideradas protegidas pois, têm ampla distribuição geográfica e são muito freqüentes em suas áreas de ocorrência.

Os principais caracteres diagnósticos utilizados para a separação das espécies foram a pilosidade dos filetes, a cor e o tipo morfológico da corola, a caducidade das estípulas, a espessura, a forma dos ramos e da folhas.

Discorda-se de Smith \& Downs (1956) quando esses autores fazem $B$. meridionalis sinônimo de $B$. australis afirmando que tanto a descrição quanto a figura originail de Exostema australe indicam flores 5-meras, não sendo portanto, possível usar esse nome como basiônimo de uma espécie que tem sempre flores 4-meras. Schumann (1889) afirma que embora Saint-Hilaire tenha indicado e representado uma espécie 5-mera tal caráter nunca foi por ele observado. Ao se analisar o material disponível observou-se que as inflorescências possuem tanto flores 4-meras quanto 5-meras, que são geralmente aquelas encontradas nas porções terminais das ramificações. Constatou-se também que nenhuma inflorescência da referida espécie possui flores exclusivamente 5-meras. Manteve-se assim o epíteto específico australis. Além disso B. australis é o binômio mais antigo.

Foi escolhido um lectótipo para a espécie B. nicholsonii, a coleta de Glaziou 13949, que se encontra no herbário do Museu Nacional do Rio de Janeiro.

\section{AGRADECIMENTOS}

À Professora. Ariane Luna Peixoto, que me iniciou na Botânica, pela orientação segura, pelo incentivo em todos os momentos e pela convivência enriquecedora. Ao Conselho Nacional de Pesquisa (CNPq) e à Coordenadoria de Apoio a Pesquisa de Ensino Superior (CAPES) pelas bolsas de pesquisa.
Aos professores da Área de Botânica da Universidade Federal Rural do Rio de Janeiro, especialmente a Maria Mercedes Teixeira da Rosa, Inês Machline Silva, Genise Vieira Somner, Marilena de Meneses Silva Conde e Lana da Silva Sylvestre pelo companheirismo no campo e constante discussão do tema. Ao Dr. Enrique Forero, na época no Missouri Botanical Garden, pelo envio de cópia de material bibliográfico. À Profa. Maria Regina de Vasconcelos Barbosa, da Universidade Federal da Paraíba, pelo incentivo e envio de cópia de material bibliográfico do Royal Botanic Gardens de Kew. Ao Pedro Paulo da Cunha Machado, amigo de longa data, pela colaboração prestada na parte de informática. Ao Dr. Symon Mayo, do Royal Botanic Gardens de Kew, pelo envio de fotografias de tipos.

\section{REFERÊNCIAS BIBLIOGRÁFICAS}

Barroso, G. M., Peixoto, A. L., Costa, C. G, Ichaso, C. L. F., Guimarães, E. F. \& Lima, H. C. 1986. Sistemática das Angiospermas do Brasil, 3, Imprensa Universitária UFV. Viçosa. p.

Benoist, M. R. 1920. Descriptions d'espéces nouvelles de Phanérogames. Bull. Mus. Hist. Nat. Paris. 26: 185.

Brummit, R. K. \& Powell, S. E. (eds.). 1992. Authors of plants names. Royal Botanic Gardens, Kew. p.

Candolle, A. P de. 1828. Rubiaceae. In: Prodromus Systematis Naturalis Regni Vegetabilis, 4: Treuttel \& Würtz. Paris.

Correa, M. P. 1984. Dicionário das plantas úteis do Brasil e das exóticas cultivadas 1.Min. Agric. Rio de Janeiro. 747 p.

Cunha, N. S. 1937. Uma perícia farmacognóstica e falsas quinas do Brasil. Rev. da Associação brasileira de farmacêuticos R. J. 18(4): 156-168.

Delprete, P. G. 1996. Notes on calycophyllous Rubiaceae. Part I. Morphological Comparison of the genera Chimarrhis, 
Bathysa and Calycophyllum. Brittonia. 48: 35-44.

Delprete, P. G. 1997. Notes on calycophyllous Rubiaceae. Part II. Morphological Comparison of the genera Bathysa and Schizocalyx. Brittonia. 49(4): 480-486.

Dwyer, J. D. 1968. Bathysa. In: DWYER. J. D. \& HAYDEN, S. M. V. 1968. New and Noteworth woody Rubiaceae of Panama. Ann. Missouri Bot. Gard. 55: 34.

Dwyer. J. D. 1980. Rubiaceae In: Flora of Panama. Ann. Missouri Bot. Gard. 67: 227-522.

Fahn, A. 1979. Secretory tissues in plants. Academic, London. Press. 302 p.

Germano-Filho, P \& M. Gomes. 1996. Rev. Univ. Rural, Sér. Ciênc. Vida 18(1-2): 21-24.

Glaziou, A. F. M. 1905. Rubiaceae. In: Liste des plantes du Brésil Central recueilles en 18611895. Bull. Soc. Bot. France. 52(mém. 3): 338.

Hickey, L. J. 1973. Classification of the architecture of dicotyledonous leaves.Amer. J. Bot. 60(1): 17-33.

Hoehne, F. C. 1939. Plantas e substâncias vegetais tóxicas e medicinais. Graphicars. São Paulo. 335 p.

Holmgren, P. K.; Holmgren, N. H. \& Barnett, L. C. 1990. Index Herbariorum. The Herbario of the world. Part I. $8^{\mathrm{a}}$. ed. New York Botanical Garden. New York. 693 p Hooker, J. D. 1873. Rubiaceae. In: BENTHAN, G. \& HOOKER, J. D. Genera Plantarum 2. Londini.

Instituto De Botânica. 1990. A Serra do Mar: degradação e recuperação. São Paulo, Boletim do Instituto de Botânica. Série Documentos. 56 p.

Klotzsch, J. F. 1846. Rubiaceae. In: HAYNE, F. G. Getreve Darstellung und Beschreibung der Arzneykunde gebrauchlichen Gewacchse. v. 14.

Krause, K. 1909. Rubiaceae. In: Verh. Bot. Vereins Prov. Brandenburg. 50: 96-97.

Leoni, S. L. 1995. Fitoterapia no Parque Estadual da Serra do Brigadeiro-MG. Pabstia. 7(1): $1-5$.
Lersten, N. R. 1974. Morfology and distribuition of colleters and cristals in relation to the taxonomy and bacterial leaf nodule symbiosis of Psychotria (Rubiaceae). Amer. J. Bot. 61: 973-981.

Presl, K. B. 1845. Bathysa. Abh. Königl. Böhm. Ges. Wiss. 3: 514-515. (reimp. Bot. Bemerk.. 84. 1844).

Radford, A. E. 1986. Fundamental of Plant Systematics. Harper \& Row, Publ. Inc. New York. 498 p.

Rambo, B. 1950. A "Porta de Torres": Estudo Fitogeográfico. An. Bot. Herbário Barbosa Rodrigues. 2: 134.

Rizzini, C. T. 1977. Sistematização terminológica da folha. Rodriguésia 29(42): 103-125.

Robbrecht, E. 1988. Tropical woody Rubiaceae. Characteristic features and progressions. Contribuition to a new subfamilial classification. Opera Bot. Belg. 1: 1-272.

Saint-Hilaire, A. de. 1824. Plants Usuelles des Brasiliens. Grimbert Libraire. Paris.

Schumann, K. 1889. Rubiaceae. In: Martius, C. F. P., Flora brasiliensis 6(6): 1-442.

Smith, L. B. \& Downs, R. J. 1956. Notulae Rubiacearum. Sellowia, 7: 88.

Standley, P. C. 1931. The Rubiaceae of Bolivia. Field Mus. Nat. Hist., Bot. Sev. 7: 280

Steyermark, J. A. 1966. The genus Bathysa in Venezuela. Bol. Soc. Venez. Nat. 26: 481.

Steyermark, J. A. 1974. Rubiaceae. In: T. Lasser (ed.), Flora de Venezuela. 9(1): 405-408. Instituto Botânico, Caracas.

Velloso, J. M. C. 1825. Florae Fluminensis 2.Typographia Nationali. Rio de Janeiro.

Verdcourt, B. 1958. Remarks on classification of Rubiaceae. Bull. Jard. Bot. État. Brux. 28(3): 209-290.

Weberling, F. \& Schwantes, H. O. 1986. Taxionomia Vegetal. Editora Pedagógica e Universitária Ltda. São Paulo. 314 p.

Willians, L. O. 1964. Tropical American PlantsVI. Fieldiana Bot. 31: 44-45. 


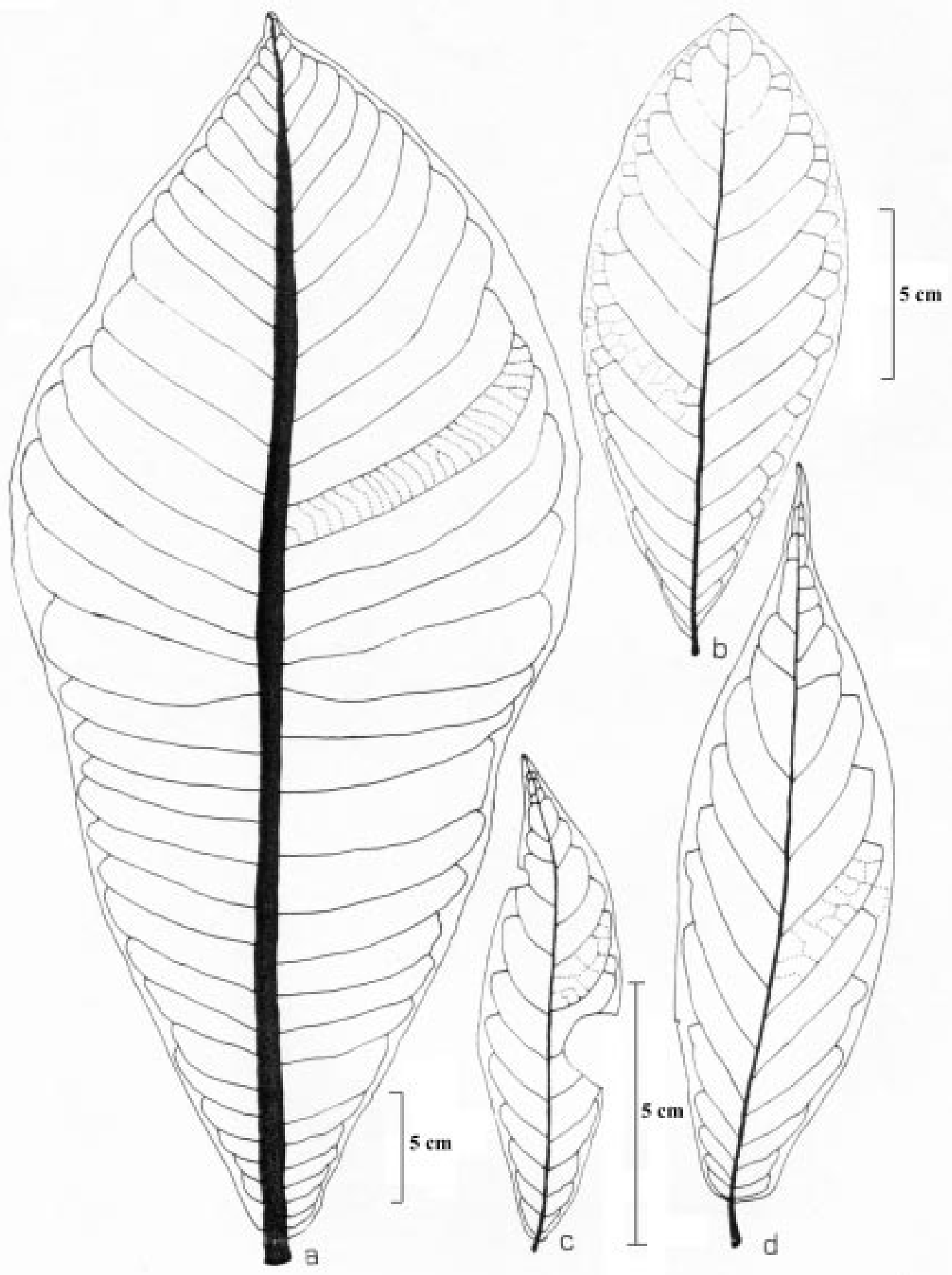

Figura 1. Aspecto geral da nervação foliar: A) Bathysa cuspidata; B) B. nichosonii; C) B. mendoncaei; D) B. sylvestrae. 


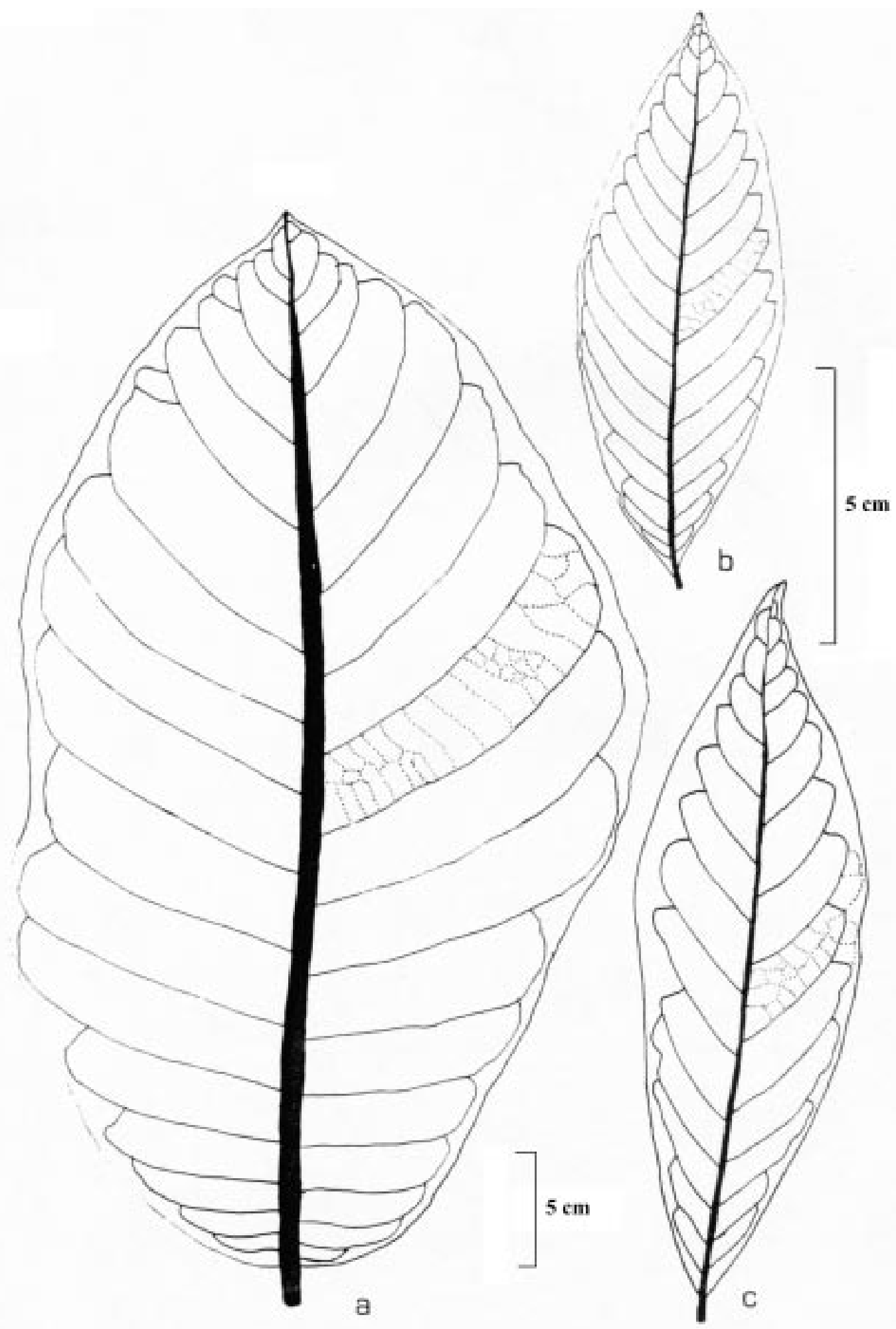

Figura 2. Aspecto geral da nervação foliar: A) Bathysa australis; B) B.gymnocarpa; C) B. stipulata. 

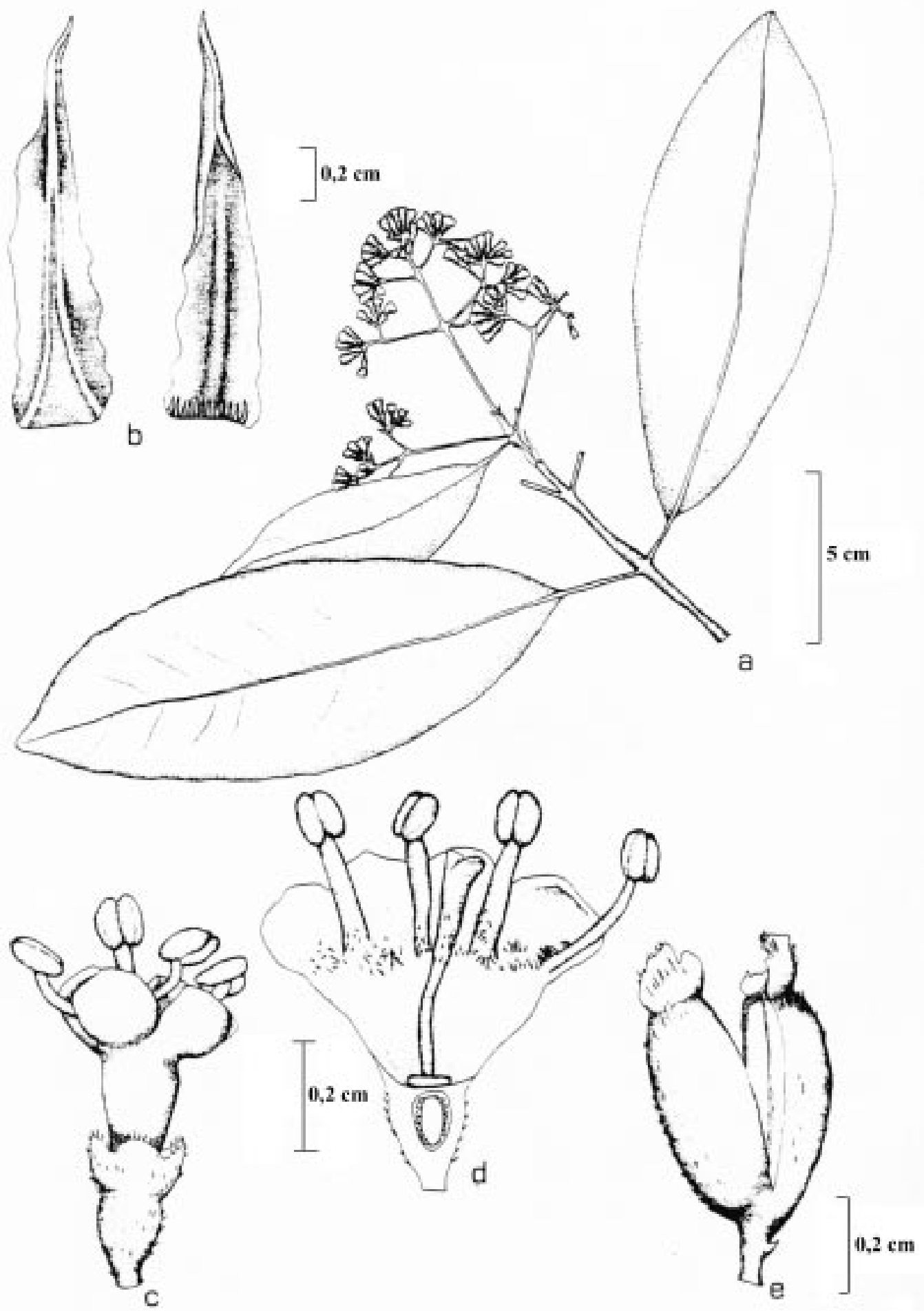

Figura 3. Bathysa mendoncaei: A) Habitus; B) estípulas, faces dorsal e ventral, com coléteres na base; C) detalhe da flor; D) Corola, corte longitudinal mostrando os estames e o gineceu; frutos, com valvas abertas. A) Araujo 977; B-E) Lanna-Sobr. 167. 


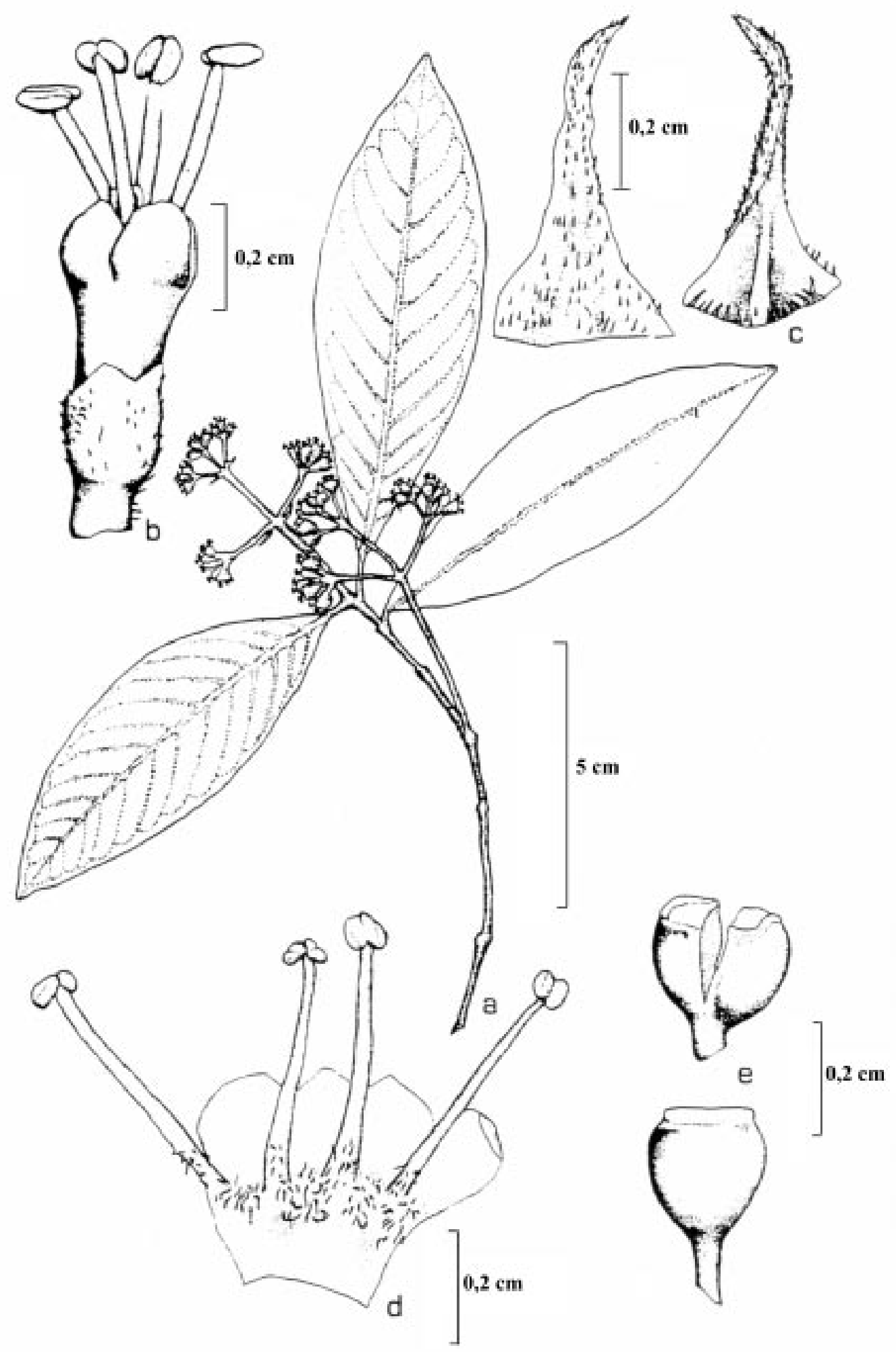

Figura 4. Bathysa gymnocarpa: A) habitus; B) detalhe da flor mostrando os estames com anteras dispostas horizontalmente; C) estípula, faces dorsal e ventral mostrando os coléteres na base. A-E) Germano-Filho 47. 


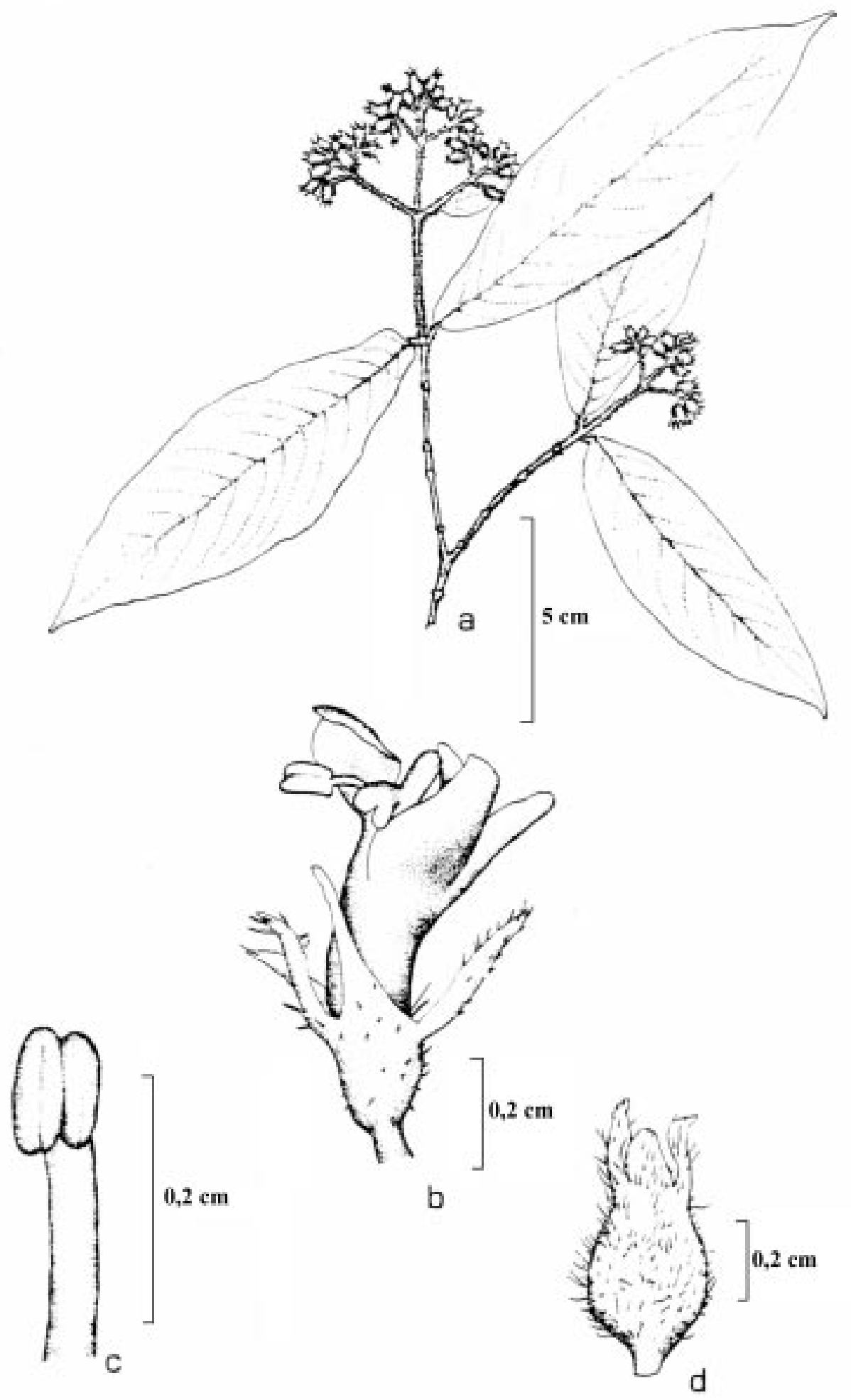

Figura 5. Bathysa sylvestrae: A) habitus; B) detalhe da flor; C) estame com filete glabro; D) fruto. A-D Sylvestre 787. 


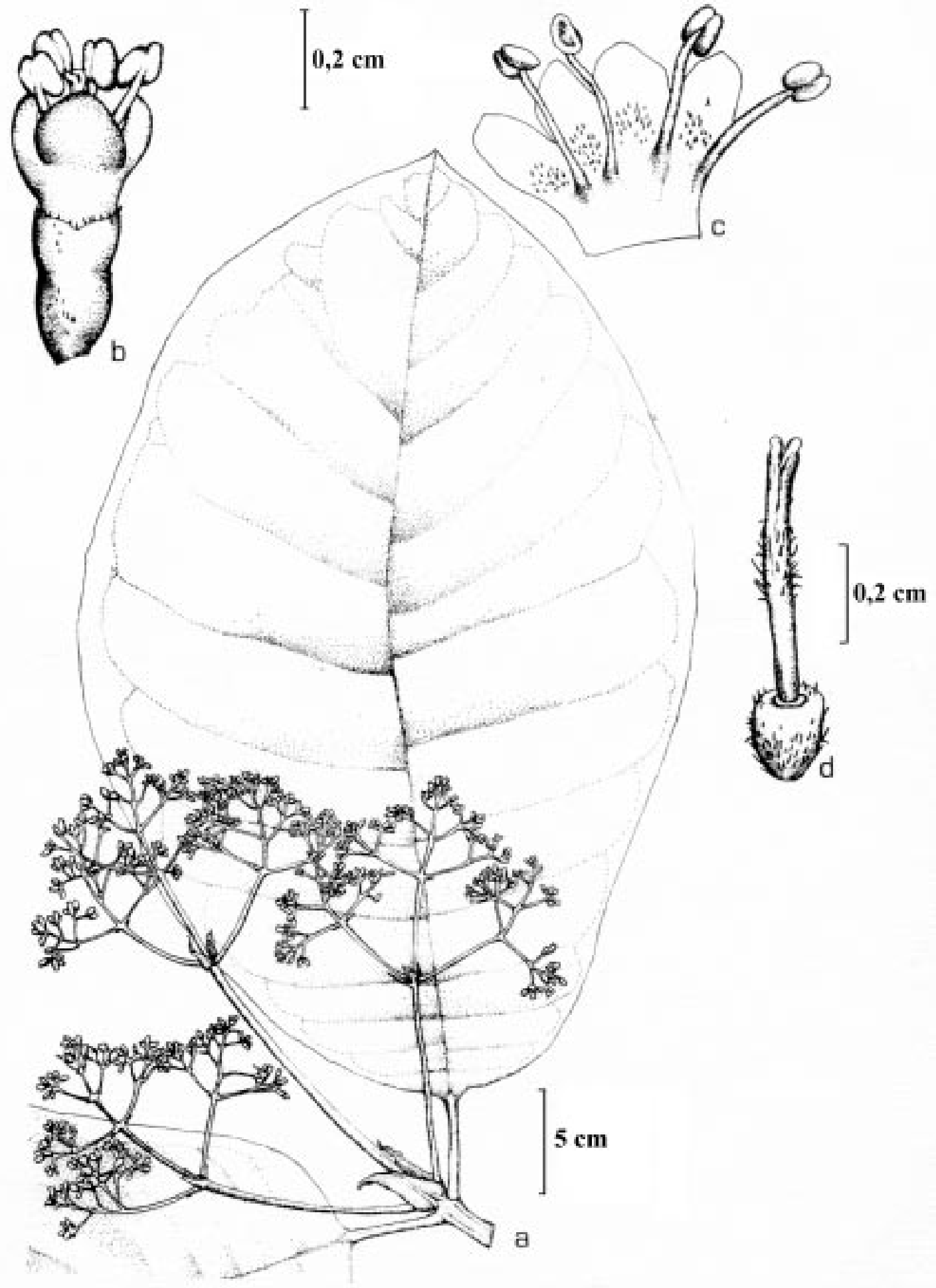

Figura 6. Bathysa australis: A) habitus; B) detalhe da flor; C) corola, face interna mostrando os estames de filetes glabros; D) gineceu. A) Machline 196; B) Germano-Filho 49; C) Reitz 4602. 


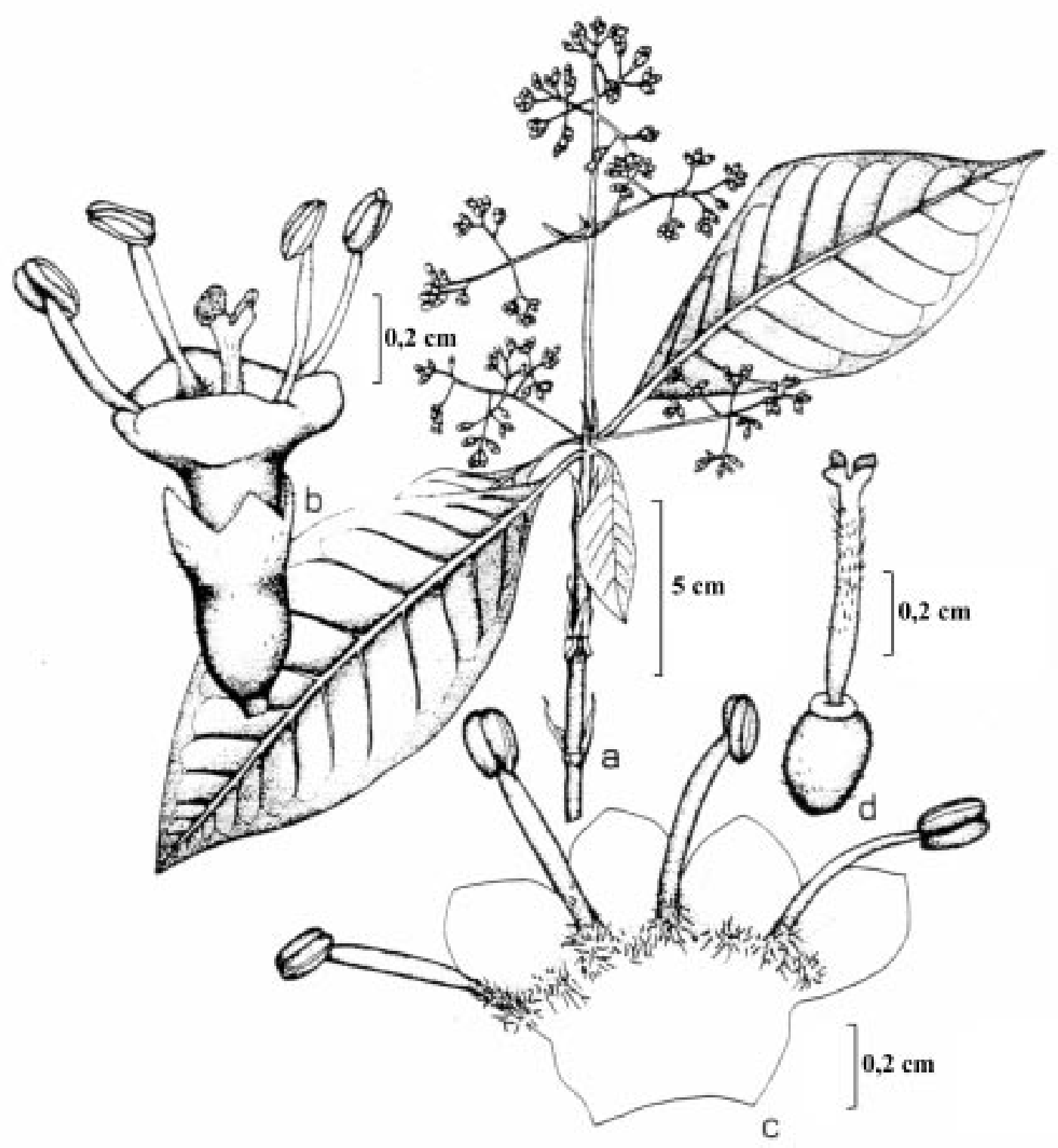

Figura 7. Bathysa stipulata: A) habitus; B) detalhe da flor; C) corola, face interna mostrando os estames com filetes pilosos na base; D) gineceu. A-D) $G$ 


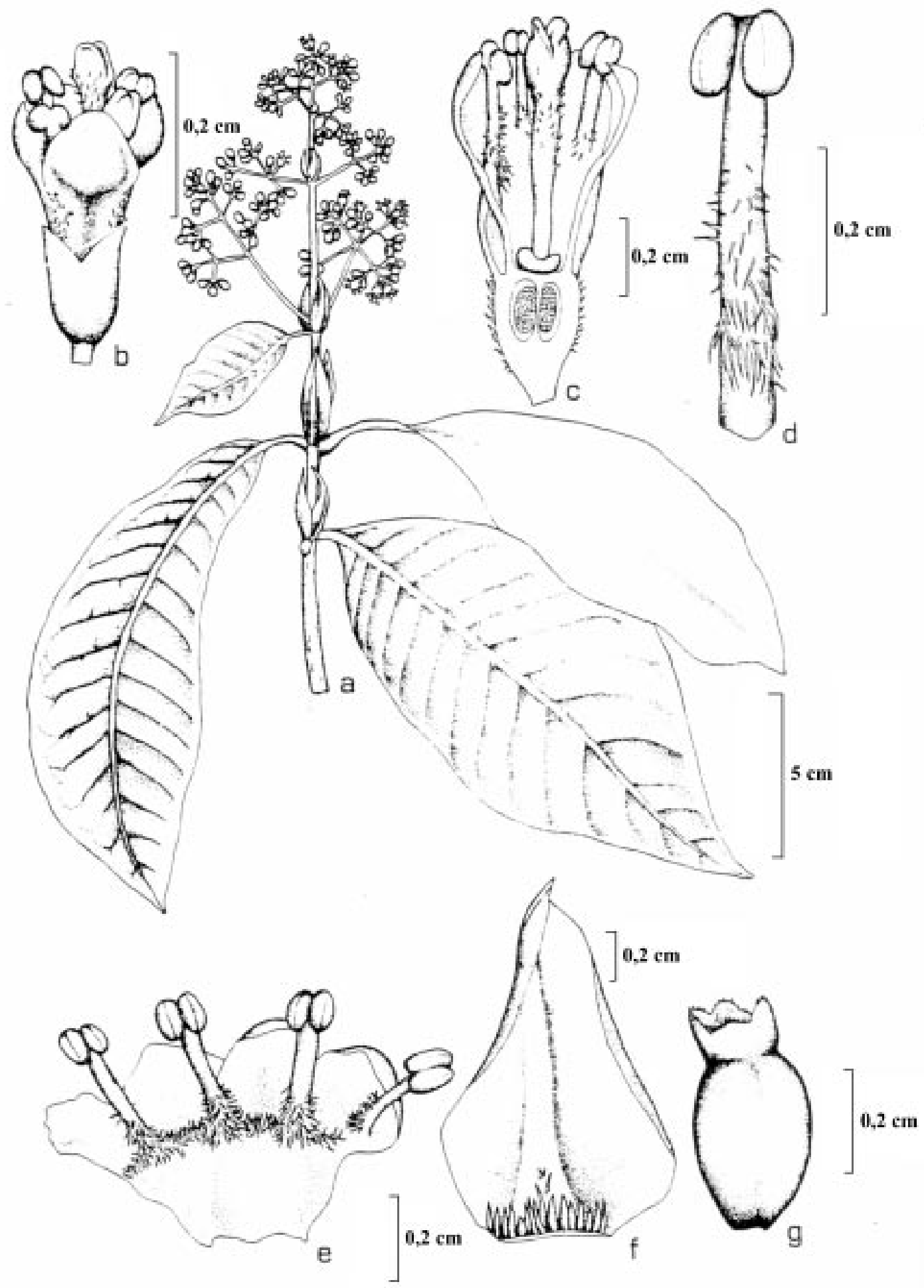

Figura 8. Bathysa nicholsonii: A) habitus; B) detalhe da flor; C) flor, corte longitudinal mostrando os estames e o gineceu; D) estame, com filete piloso; E) corola, face interna mostrando os estames; F) estípula; face ventral mostrando os coléteres na base; G) fruto. A-G) Germano-Filho 46. 


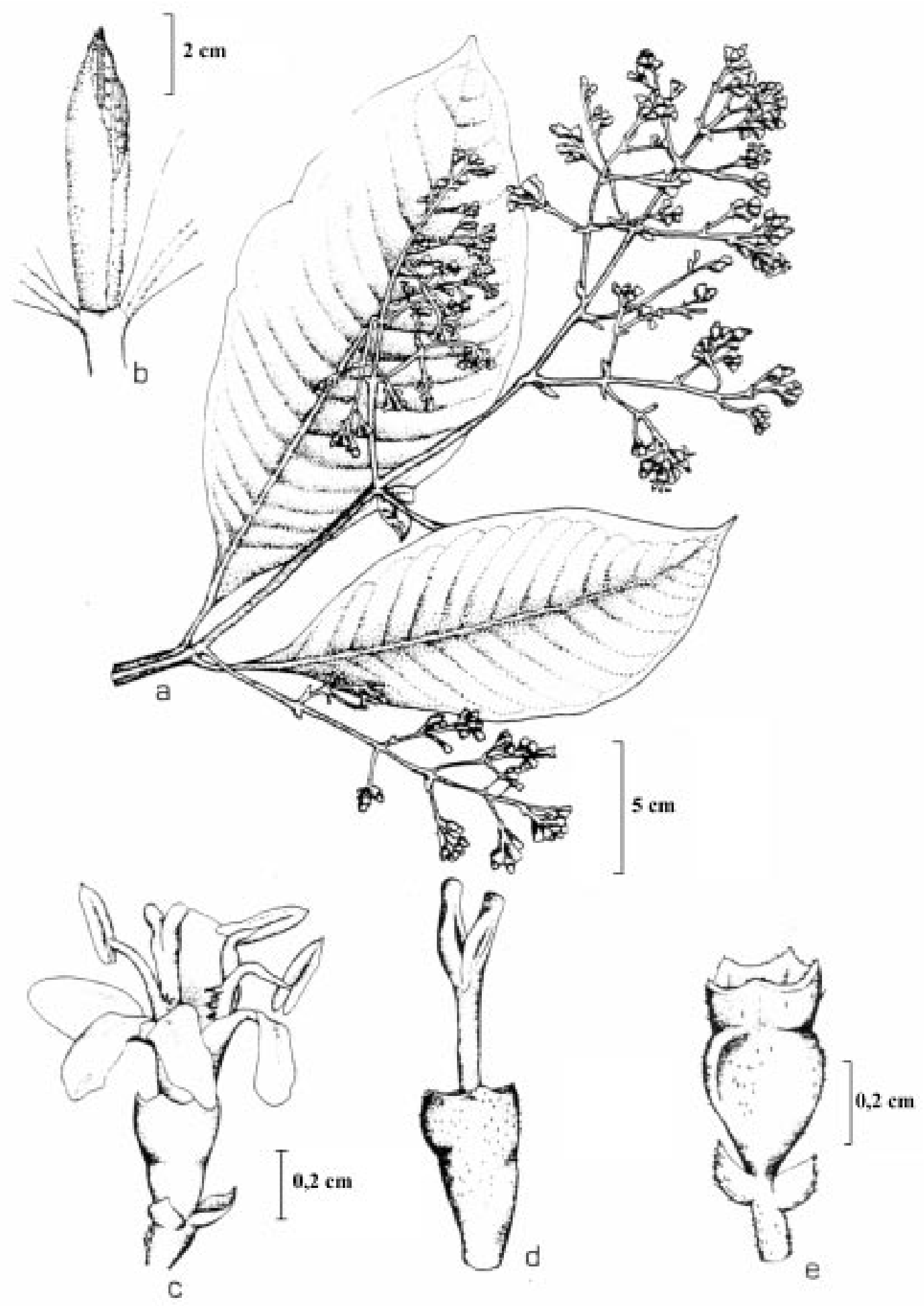

Figura 9. Bathysa cuspidata: A) habitus; B) estípulas unidas entre si; C) detalhe da flor, mostrando os lobos reflexos e os estames de anteras sagitadas; D) flor, removidos corola e estames, mostrando o estilete; D) fruto. A) Brade 18211; B) Heringer s. n.; C-D) Germano-Filho 53.

Rodriguésia 50(76/77): 49-75. 1999 
